\title{
TITLE:
}

\section{ASCIDIANS FROM MINDORO ISLAND, THE PHILIPPINES}

AUTHOR(S):

Tokioka, Takasi

\section{CITATION:}

Tokioka, Takasi. ASCIDIANS FROM MINDORO ISLAND, THE PHILIPPINES. PUBLICATIONS OF THE SETO MARINE BIOLOGICAL LABORATORY 1970, 18(2): 75-107

ISSUE DATE:

1970-10-20

URL:

http://hdl.handle.net/2433/175626

RIGHT: 


\section{ASCIDIANS FROM MINDORO ISLAND, THE PHILIPPINES ${ }^{13}$}

\section{TAKASI TOKIOKA}

Seto Marine Biological Laboratory

With 12 Text-figures

A small but very important collection of ascidians made at Puerto Galera, Mindoro Island, the Philippines was submitted to me for identification by the Biological Laboratory in the Imperial Household. The collection which was made by Messrs. R. Guerrero and R. Diaz in April and May 1963 and then had belonged to the Department of Zoology, the University of the Philippines, was presented from the President of the Philippines to His Majesty the Emperor of Japan for professional investigations. The following fifteen forms were found in the collection; one of them seemingly represents a new species and six species and one form which are marked with an asterisk on the list given below are recorded newly from Philippine waters.

\section{Ascidians found in the collection}

Fam. Didemnidae

1. Didemnum (Didemnum) candidum $\mathbf{S}$ Avigny

2. Didemnum (Didemnum) moseleyi (Herdman)

*3. Didemnum (Didemnum) moseleyi f. granulatum ToкıокA

4. Diplosoma macdonaldi Herdman

Fam. Polycitoridae

5. Nephtheis fascicularis (Drasche)

Fam. Ascidiidae

6. Ascidia sydneiensis samea (OKA)

7. Phallusia depressiuscula (HelleR)

Fam. Styelidae

*8. Polyandrocarpa nigricans (HeLLeR)

9. Polycarpa aurata (Quoy et Gaimard)

*10. Polycarpa cryptocarpa (SLUITER)

*11. Polycarpa iwayamae Tokioka

1) Contributions from the Seto Marine Biological Laboratory, No. 523.

Publ. Seto Mar. Biol. Lab., XVIII (2), 75-107, 1970. (Article 8) 
*12. Polycarpa papillata (Sluiter)

*13. Polycarpa cylindrocarpa n. sp.

Fam. Pyuridae

*14. Pyura sp. aff. lignosa Michaelsen

15. Herdmania momus (SAvignY)

So far as the accessible papers are concerned, 86 species of ascidians have been known from Philippine waters. By the present addition of seven more species (including one form), the Philippine ascidian fauna will grow up to cover 93 species including a few varieties and formae. As this addition is rather significant, it is desirable that the present identification will be later checked carefully by some other researchers. To make this possible, the descriptions accompanied with some figures are repeated here for most species.

The list of Philippine ascidians was first compiled by VAN NAME in 1918, when he described 45 species collected in Philippine waters by the Albatross Expedition and at the same time listed 26 other species which had ever been collected from the same waters by the Challenger and Siboga Expeditions, but were not included in the Albatross collection. Later, fifteen more species were found in the material of ascidians collected in Philippine waters and deposited in the United States National Museum (Toкioka, 1967). Dealing the ascidians of the present collection together with those 86 species, the following list is given to show the present status of the known Philippine ascidian fauna.

\section{Ascidians of the Philippines}

Order Aplousobranchia

Family Synoicidae

1. Aplidium depressum Sluiter (VN) ......See VAn Name (1918).

1a. Aplidium sp. aff. depressum Slutter (TK)...... See Токіока (1967).

2. Aplidium fumigatum Herdman ( $\mathrm{CH})$......By Challenger Exped.

3. Amaroucium constrictum SLutter (VN)

4. Amaroucium multiplicatum (SLUITER) (VN)

5. Amaroucium crateriferum SLUITER (VN)

6. Synoicum tropicum (Sluiter) (SB) .......By Siboga Exped.

7. Synoicum intercedens (SLUITER) (SB)

8. Polyclinum festum Hartmeyer (VN)

9. Polyclinum mikropnous Sluiter (SB)

10. Polyclinum vasculosum Pizon (TK)

11. Polyclinum tsutsuii Tokioka (TK)

Family Didemnidae

12. Didemnum (Didemnum) candidum (SAVIGNY) (TK)

13. Didemnum (Didemnum) moseleyi (Herdman) (VN, TK) 
14. Didemnum (Didemnum) moseleyi f. granulatum TokıокA

15. Didemnum (Didemnum) grande (Herdman) (VN)

16. Didemnum (Didemnum) digestum Sluiter (SB)

17. Didemnum (Didemnum) makropnous SLUiter (SB)

18. Didemnum (Didemnum) ramosum Sluiter (SB)

19. Didemnum (Didemnum) nekozita Tокіока (TK)

20. Didemnum (Didemnum) dorotubu Tokioka (TK)

21. Didemnum (Didemnum) misakiense (OKa et WILlEY) (TK)

22. Didemnum (Didemnum) ternatanum (GotTsahaldT) (VN, TK)

23. Didemnum (Polysyncraton) dubium SLuiter (VN)

24. Trididemnum savignii (Herdman) (TK)

25. Trididemnum savignii var. jolense (VAN NAME) (VN, TK)

26. Trididemnum granosum SluIter (SB)

27. Trididemnum viride (Herdman) (TK)

28. Echinoclinum philippinense Токıока (TK)

29. Lissoclinum molle (HerdmaN) (SB)

30. Lissoclinum fragile (VAN NAME) (TK)

31. Lissoclinum patella (GotTschaldT) (TK)

32. Lissoclinum pulvinum (TокIOKA) (TK)

33. Diplosoma macdonaldi Herdman (VN)

34. Diplosoma calificiforme (SlutTer) (VN)

35. Diplosoma virens (HARTMEYeR) (TK)

Family Polycitoridae

36. Clavelina molluccensis (SLUITER) (VN)

37. Clavelina detorta (SLuiter) (VN)

38. ?Eudistoma tokarae Tokioka (TK)

39. Polycitor ianthinus Slutter (VN)

40. Polycitor torosus Sluiter (VN)

41. Polycitor discolor Sluiter (SB)

42. Polycitor sedens (Sluiter) (SB)

43. Cystodytes philippinensis Herdman (CH, VN)

44. Cystodytes rufus SLuiter (SB)

45. Cystodytes semicataphractus SLuiter (SB)

46. Distaplia vallii Herdman (VN)

47. Sycozoa pulchra (Herdman) (VN)

48. Nephtheis fascicularis (Drasche) (VN)

Order Phlebobranchia

Family Diazonidae

49. Rhopalopsis crassa (HERDMAN) (VN)

Family Cionidae

50. Ciallusia longa VAN NAme (VN) 
Family Perophoridae

51. Perophora hutchisoni MacDonald (VN)

52. Ecteinascidia diaphanis SluITER (SB)

53. Ecteinascidia garstangi Sluiter (SB)

Family Ascidiidae

54. Ascidia sydneiensis samea (ОкA) (TK)

55. Ascidia aperta SLuiter (VN)

56. Ascidia melanostoma Sluiter (SB)

57. Phallusia kreagra (Sluiter) (SB)

58. Phallusia depressiuscula (HELler) (VN)

Family Rhodosomatidae

59. Rhodosoma turcicum (SAVIGNY) (VN)

60. Chelyosoma sibogae SLuiter (SB)

Order Stolidobranchia

Family Botryllidae

61. Botrylloides tyreum Herdman (VN)

62. Botrylloides perspicuum Herdman (CH)

63. Botrylloides perspicuum var. rubicundum Herdman (CH)

Family Styelidae

64. Symplegma monocarpa var. philippinensis (MichaELsEN) (CH)

65. Stolonica vesicularis VAN NAME (VN)

66. Stolonica styeliformis VAN NAME (VN)

67. Polyandrocarpa (Eusynstyela) latericius (SLUITER) (VN)

68. Polyandrocarpa maxima (SLUITER) (VN)

69. Polyandrocarpa nigricans (HELLER)

70. Polycarpa circumarata (SLUiter) (VN)

71. Polycarpa aurata (Quoy et GAImARD) (VN)

72. Polycarpa pedata Herdman (VN)

73. Polycarpa quadrata Herdman (VN)

74. Polycarpa ovata Pizon (VN)

75. Polycarpa cryptocarpa (Sluiter)

76. Polycarpa iwayamae TокіокA

77. Polycarpa procera (SLUITER) (SB)

78. Polycarpa irregularis Herdman (CH)

79. Polycarpa thelyphanes (SLUITER) (SB)

80. Polycarpa papillata (Sluiter)

81. Polycarpa cylindrocarpa n. sp.

82. Cnemidocarpa areolata (HELLER) (VN)

83. Cnemidocarpa tinaktae (VAN NAME) (VN)

84. Cnemidocarpa maeandria (SLUIter) (VN) 
Family Pyuridae

85. Pyura intermedia (VAN Name) (VN)

86. Pyura duplicata VAN NAME (VN)

87. Pyura jacatrensis (Sluiter) (SB)

88. Pyura sp. aff. lignosa Michaelsen

89. Pyura inflata VAN NAme (VN)

90. Herdmania momus (SAvignY) (VN)

91. Microcosmus exasperatus HeLleR (VN)

92. Culeolus thysanotus SLutTer (SB)

Family Molgulidae

93. Molgula vitrea SLUiter (VN)

At closing the introductory remarks, I wish earnestly to express here my hearty thanks to those who were concerned in making the present collection and in granting me the privilege of examining the material.

\section{Descriptions}

\section{Didemnum (Didemnum) candidum SAVIGNY}

(Figs. 1, 1-3)

Two small colonies encrusting the surface of Herdmania momus (Savigny) Sp. No. 957a. They are respectively $10 \mathrm{~mm} \times 4 \mathrm{~mm}$ and $3 \mathrm{~mm} \times 2 \mathrm{~mm}$ in extent and about $1 \mathrm{~mm}$ in thickness; snowy white, impregnated with small spicules very densely from the surface to the bottom. The superficial spiculeless layer is insignificant, though it is discernible at some parts of the periphery. Zooids are distributed $300-600 \mu(435 \mu$ on an average) apart from one another, and the colony surface is raised a little above respective zooids. Spicules are 21 to $29 \mu$ in diameter, $24 \mu$ on an average; rays are rather slender and with a somewhat blunt tip; usually 7 to 10 rays on the equatorial plane. The larger colony is provided with a single common cloacal aperture near one end of the colony, the aperture is elongate, spindle-shaped, and $830 \mu$ in length. The lacunae are well defined, though they are limited to the thoracic layer. The thorax is about $200 \mu$ in a contracted state; the atrial aperture very wide; no atrial languet; about half a dozen stigmata in each stigmatal row on each side. The abdomen is about $330 \mu$ long; the alimentary canal is looped roughly horizontally. A single testicular follicle is present, the vas deferens coils 5-9, most frequently 5-6 times.

Remarks: The spicule rays are rather few for this species, but their appearance, slender and with a blunt tip, and the lesser size of spicules may be accepted together as the sign of Didemnum candidum. The size of zooids, the structure of the colony, and the distribution of spicules are of course in the range of this species. 
Three other small colonies were found on the peduncles of Nephtheis fascicularis (Drasche). They are a $4 \mathrm{~mm} \times 2.5 \mathrm{~mm}$ colony, a $7 \mathrm{~mm} \times 5 \mathrm{~mm}$ colony, and a heavily damaged one. The colony in the best state is shown in Fig. 1-2. Colonies are rather soft, the surface is markedly coloured in white and sepia as shown in the text-figure. Extensions of the test around the periphery are nearly transparent. Spicules are rathre sparse, especially less dense in the abdominal layer. They are very small, $17-27 \mu$ in diameter, and about $20 \mu$ on an average. Spicule rays are numerous, short, and nearly truncate at the tip; thus smaller spicules are nearly spherical in shape. A single spindle-shaped common cloacal aperture is found on the colony figured. The lacunae are very spacious extending from the thoracic to the abdominal layer, the abdomens are placed horizontally on the thin colony floor. The thorax is about $400 \mu$ in length, the atrial aperture is very wide, no atrial languet; about 10 stigmata in each of 4 rows on each side. The abdomen is $480 \mu$ long. The hind stomach and the mid-intestine are rather distinct. The gonad was not found in any zooids. As some species of the genera Didemnum and Lissoclinum resemble so closely one another in the general structure of the colony, zooids, and spicules and are separable only by the gonadal structure, the exact situation of the present colonies is uncertain. If these are truly colonies of a form of the genus Didemnum, then these must be $D$. (D.) candidum, because of the characteristic shape of spicules (Fig. 1-3). However, spicules of such a type occur also in some species of Lissoclinum. Somewhat soft and then fragile test, very spacious lacunae, and zooids a little larger in these colonies imply the possibility that the colonies belong to a form of the genus Lissoclinum.

\section{Didemnum (Didemnum) moseleyi (HERDMAN)}

(Fig. 1, 4-5)

Four small colonies from the surface of Herdmania momus (SAvigny) Sp. No. 957a. They are respectively $17 \mathrm{~mm} \times 10 \mathrm{~mm}, 13 \mathrm{~mm} \times 10 \mathrm{~mm}, 8 \mathrm{~mm} \times 5 \mathrm{~mm}$, and $5 \mathrm{~mm}$ $\times 3 \mathrm{~mm}$ in extent and 1-2 $\mathrm{mm}$ in thickness. The superficial spiculeless layer is generally thin, but partially, chiefly at some marginal portions, it is of a significant thickness. Brownish pigments are deposited at the bottom of this layer to form a brown and white pattern on the colony surface (Fig. 1-4). The periphery is always whitish. One or two common cloacal apertures on each colony. Apertures are elongate, cleft-shaped, and $200-625 \mu$ in length. Zooids are distributed $400-710 \mu$, $543 \mu$ on an average, apart from one another. The colony is impregnated with spicules densely, except for the ceiling of the lacuna system leading to the common cloacal apertures. There the spicules are sparse and especially they are entirely missing around the aperture. Spicules are rather large, 36-79 $\mu$ in diameter and $53 \mu$ on an average. About eight rays on the equatorial plane. Rays are stout and sharply pointed in smaller spicules, while they are somewhat elongate and ending bluntly at the tip in very large ones. The lacunae are very spacious, extending from 
the thoracic to the abdominal layer. In the result, respective abdomens are placed horizontally on the colony floor. The thorax is about $500 \mu$ long, the atrial aperture very wide, about 6 stigmata in each row on each side. The abdomen is about $420 \mu$

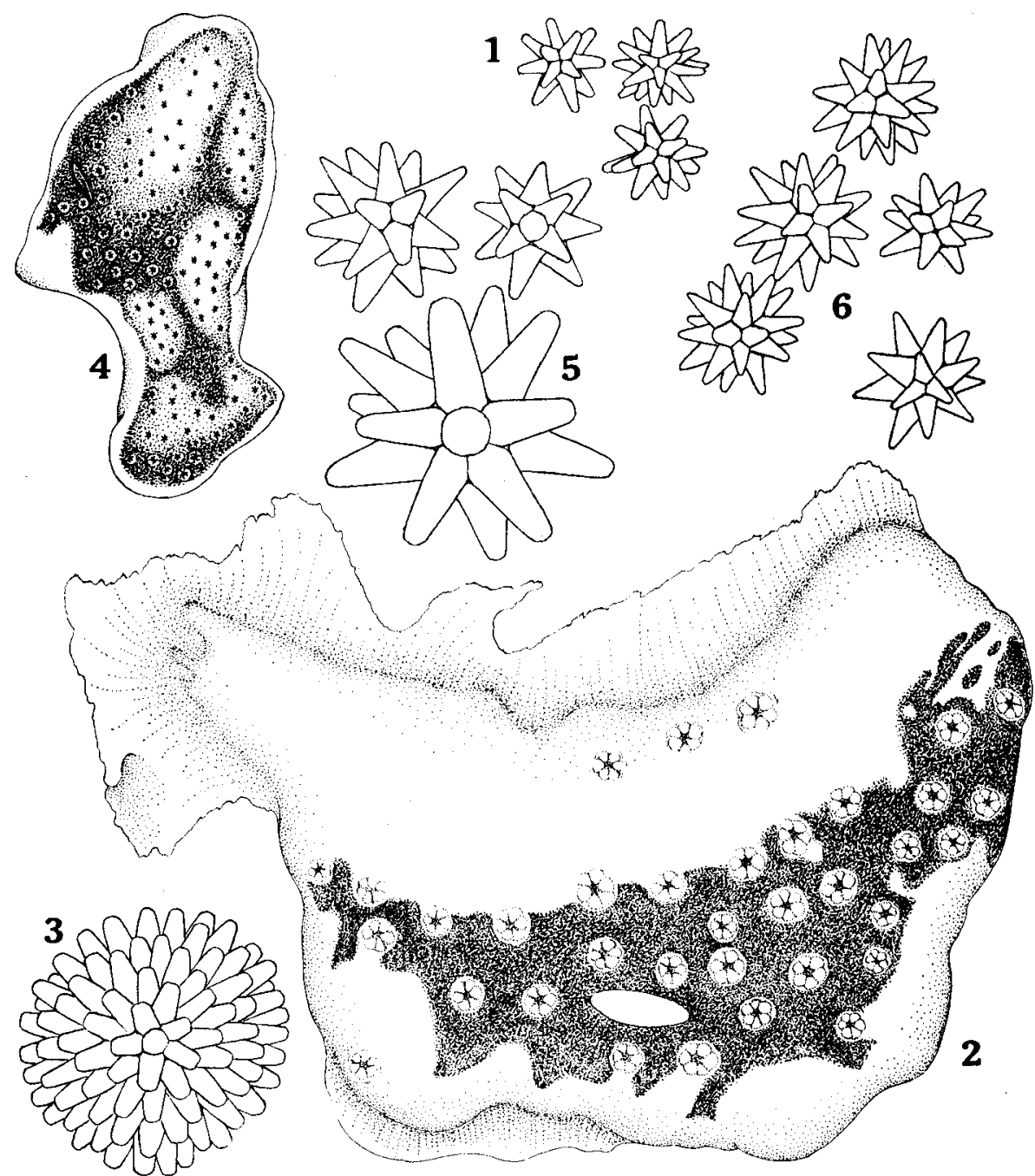

Fig. 1. 1: Didemnum (Didemnum) candidum SAviany. Spicules, $\times 440.2,3:$ Didemnum (D.) candidum or ?Lissoclinum sp. 2-Colony, $\times 24$. 3-A spicule, $\times 1200$. 4, 5: Didemnum (Didemnum) moseleyi (Herdman). 4-A $17 \mathrm{~mm} \times 10 \mathrm{~mm}$ colony. 5-Spicules from the same colony, $\times 440$. 6: Didemnum (Didemmum) moseleyi f. granulatum ToкıокA. Spicules, $\times 440$.

long, the testicular follicle 1, the vas deferens coils about 6 times. A couple of small pontelid shrimps were found in the $17 \mathrm{~mm} \times 10 \mathrm{~mm}$ colony and a syllid in the $13 \mathrm{~mm} \times$ $10 \mathrm{~mm}$ colony. 


\section{Didemnum (Didemnum) moseleyi f. granulatum ToKIOKA}

(Fig. 1, 6)

Didemnum (Didemnum) moseleyi f. granulatum-Tokroka (1954): Publ. Seto Mar. Biol. Lab., 3 (3), p. 6; pl. 21, figs. 1-4. (1967) : U.S. Nat. Mus. Bull. 251, p. 67, figs. 20 e-f.

A very extensive colony covering peduncles of a colony of Nephtheis fascicularis (Drasche) Sp. No. 958. Thus, the colony is complicatedly lobated, but probably it may attain $40 \mathrm{~mm} \times 40 \mathrm{~mm}$ or more in extent; about $1 \mathrm{~mm}$ in thickness. As the colony is faintly yellowish, it might be coloured orange to red when it was alive. The superficial spiculeless layer is insignificant. The colony surface assumes granulated; this is caused by many aggregations of spicules, which are each about $210 \mu$ in diameter. Zooids are distributed $340-490 \mu, 410 \mu$ on an average, apart from one another. The colony is impregnated with spicules very densely from the surface to the bottom. Spicules are of the moseleyi-type, 29-36 $\mu$ in diameter, and $33 \mu$ on an average. Rays are stout and pointed at the tip, 7-9 rays on the equatorial plane. Zooids are rather small. The thorax is $250 \mu$ long, with the retractile muscle as long as the thorax; the atrial aperture very wide, about 7 stigmata in each row on each side. The abdomens are buried completely in the compact abdominal layer, about $290 \mu$ long; the testicular follicle 1, the vas deferens coils at least 4 times.

\section{Diplosoma macdonaldi HERDMAN}

(Fig. 2)

Diplosoma macdonaldi-Herdman (1886): Challenger Report, Zool., vol. 14, p. 315; pl, 42, figs. 1-4. Gottschaldt (1898): Abhandl. Senckenberg. Naturf. Gesell., vol. 24, p. 657; pl. 36, fig. 5. VAN Name (1902): Trans. Connecticut Acad. Sci., vol. 11, p. 368; pl. 53, fig. 60; pl. 60, fig. 124. (1921): Bull. American Mus. Nat. Hist., vol. 44, p. 335, fig. 30. (1930): Scientific Survey of Puerto Rico and the Virgin Islands, vol. 10, part 4, p. 440, figs. 17-18. (1945): Bull. American Mus. Nat. Hist., vol. 84 , p. 109 , fig. 51 ; pl. 12, fig. 5 . 109 .

Leptoclinum macdonaldi-VAN Name (1918): U.S. Nat. Mus. Bull. 100, vol. 1, part 2, p. 159, fig.

A large colony covering the surface of Ascidia sydneiensis samea (Ока) Sp. No. 957b. The colony is $55 \mathrm{~mm} \times 35 \mathrm{~mm}$ in extent and about $1 \mathrm{~mm}$ thick in most parts, but up to $2 \mathrm{~mm}$ along the margin. The test is soft, translucent, and faintly milky white. The attachment surface is coloured faintly and irregularly in brown and green, and zooids are seen through as white objects. Generally saying, in larger zooids which have the developed testis but already released the egg the mantle covering the thorax and the alimentary canal is somewhat brownish, whereas smaller zooids keeping still a mature egg, newly liberated young zooids, and some larger zooids with fully grown bud are usually free from pigments and whitish as a whole. Thus, on the free surface of the colony, zooids are seen through the test as brownish objects in some parts or as whitish particles in other parts. The lacuna system inside the colony 
is very spacious. The surface layer of the colony including zooids is supported above the floor only by a limited number of columns or trabeculae made of test substance, and the most part of the interior is hollow. Two to fifteen zooids are resting on respective columns; some zooids may be suspended individually from the surface layer, or a few to several zooids may be hung from the surface layer in a group (Fig. 2-7). Fully mature eggs and embryos in different developmental stages are found
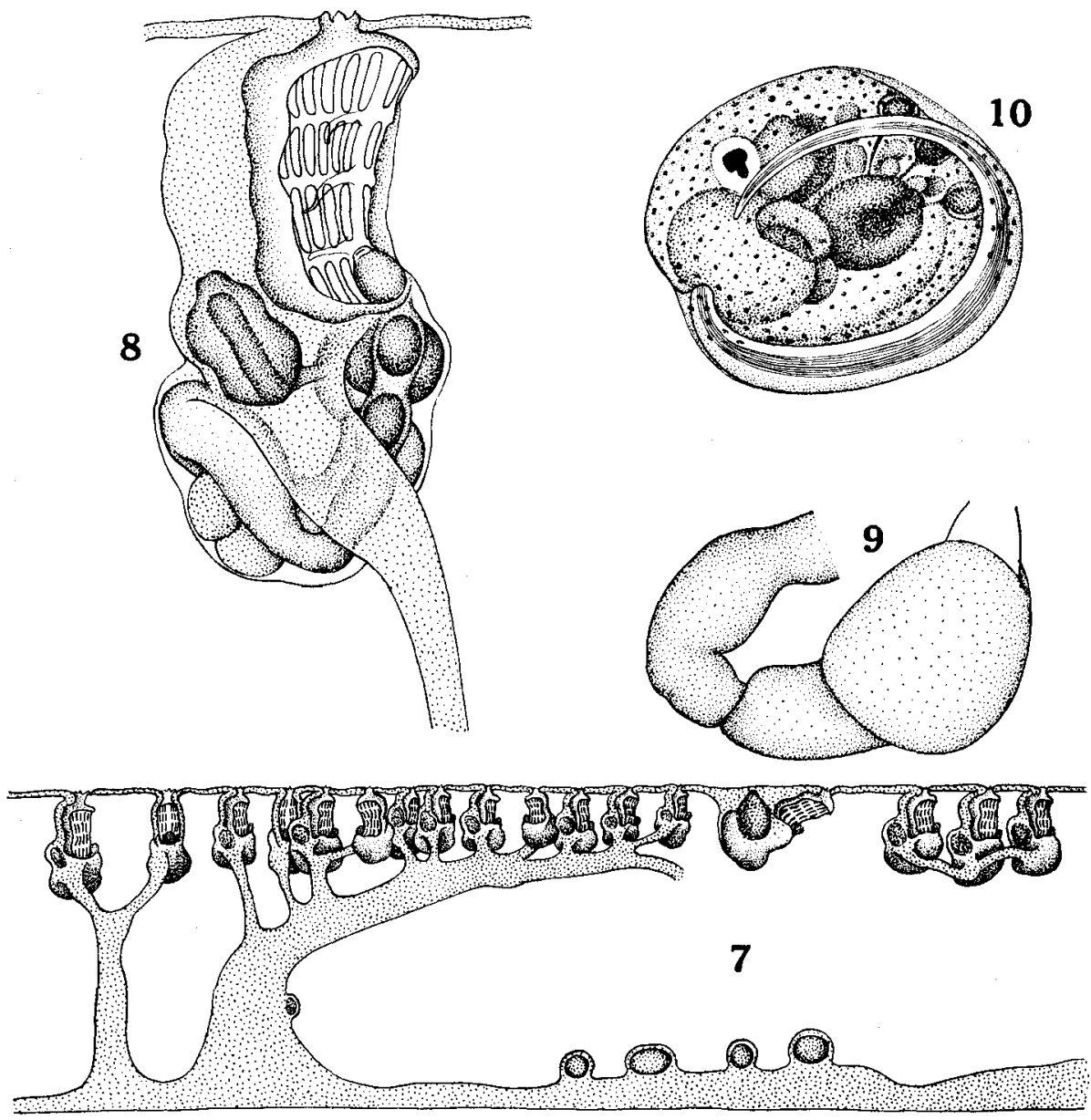

Fig. 2. Diplosoma macdonaldi Herdman. 7-Optical section of colony, shown rather schematically. 8-Left side of a zooid. 9-Alimentary canal. 10-Embryo, right side, $\times 73$.

settled on the floor and sometimes on the surface of the lower part of colunns.

The thorax is 375 to $670 \mu$ long in examined zooids, and the abdomen is about $330 \mu$ in length. The branchial aperture is six-lobed. The atrial aperture is open very widely, about $7(6-8)$ stigmata in each row on each side, dorsal languets are slender and displaced to the left side by the distance of about two stigmata. Eight branchial 
tentacles. The anus is situated near the dorso-posterior corner of the thorax, at the level of the third transverse vessel in a preserved state. The retractile muscle is of a considerable length, issued from the postero-ventral corner of the zooid, and extended into the trabecula which connects the left side of the abdomen of respective zooids, around the site of the second intestinal loop, to the column or to the trabecula of another zooid. In this way, zooids are respectively fixed firmly to the surface layer by the test substance covering the ventral half of the thorax and to the floor by the above-mentioned trabecula. The stomach is rather globular in outline (Fig. 2-9), and a little compressed laterally; the hind stomach is nearly as long as the stomach; the mid-intestine is rather indistinct. The ripe egg is about $160 \mu$ in diameter. Embryos ready to hatch are 480 to $500 \mu$ in diameter (Fig. 2-10). The larval test is markedly granulated. Two bud individuals, nearly completed in body organization, and three pairs of buds or ampullae are seen in fully developed embryos. Three attachment proc sses are cup-shaped and arranged lineally.

Remarks: The exact identification of respective species of Diplosoma may be one of the most difficult works in ascidian taxonomy. The present identification was made for the two reasons. The first is the similarity of the colony structure seen between the present colonies and the colonies occurring commonly in the West Indies. VAN NAME (for instance, 1945: pp. 109-110) mentioned repeatedly that in West Indies colonies "common cloacal cavities very extensive, though developed to a varying degree in different colonies; in extreme cases the entire interior of the colony may be hollow, except for columns or trabeculae of test substance in which the zooids are embeded." This structure given by VAN NAME is strictly applicable to the present colony from the Philippines, excepting that zooids are never embeded in columns or in trabeculae, but are only supported firmly by those structures. The second is the fact that some colonies from Philippine waters were ever identified with this species of Diplosoma by VAN NAME (1918) who had already been familiar with many colonies of $D$. macdonaldi from the West Indies in the same warm water region of the West Atlantic that includes the type locality of the species. The difficult problem presented here is to distinguish Diplosoma mitsukurii Oka from D. macdonaldi. It seems to me practically impossible to separate exactly these two species from each other. Generally saying, however, the test seems a little firmer in macdonaldi than in mitsukurii. In D. mitsukurii the pigments of the mantle covering the thorax and especially the alimentary canal are nearly constantly rather brownish purple even in preserved specimens. The colony structure given above for the present Philippine colony may appear in some colonies of $D$. mitsukurii, but usually in a very limited scale. In $D$. mitsukurii, the lacunae may be extended in some lesser scales by holding zooids by columns or trabeculae, but most frequently respective zooids are connected straight to the colony floor separately by a trabecula issued from the left side of the abdomen. If the above-mentioned characters of $D$. mitsukurii are accepted only as latitudinal variations and are insufficient to differentiate the species from D. macdonaldi, then macdonaldi should take the priority over mitsukurii. 


\section{Nephtheis fascicularis (DRASCHE)}

(Fig. 3)

Colella thomsoni-Herdman (1886): Challenger Rep., Zool., vol. 14, p. 94, pls. 10-13.

Nephtheis thomsoni-Sluiter (1909): Siboga-Exped., 56b, p. 36. Hartmeyer (1919): Kungl. Sv. Vetensk. Handl., vol. 60, no. 4, p. 121.

Nephtheis thompsoni-V V N NAme (1918): U.S. Nat. Mus. Bull. 100, vol. 1, part 2, p. 144, fig. 96.

Nephtheis fascicularis - Tокıока (1952): Publ. Seto Mar. Biol. Lab., vol. 2, no, 2, p. 100, fig. 7.

Sp. No. 958-The material includes five specimens. (1) A colony consisting of three cormidia. (2) A colony consisting of four cormidia which were covered entirely on their peduncles by an extensive colony of Didemnum (Didemnum) moseleyi f. granulatum Tokioka. (3) A cormidium with the corona $12 \mathrm{~mm}$ long $\times 13 \mathrm{~mm}$ wide and the peduncle $30 \mathrm{~mm}$ long and $6 \mathrm{~mm}$ thick. (4) A cormidium with the corona $12 \mathrm{~mm}$ long $\times 13 \mathrm{~mm}$ wide and the peduncle $16 \mathrm{~mm}$ long and $4 \mathrm{~mm}$ thick. (5) A coronal piece.

The No. 1 specimen (Fig. 3-11) is in the best state. The corona is $12-16 \mathrm{~mm}$ in length and $13-15 \mathrm{~mm}$ in the maximal width; the test is very soft gelatinous, transparent, and fragile; no surface structure was defined with certainty. The peduncle is $24-30 \mathrm{~mm}$ in length and $4-9 \mathrm{~mm}$ in diameter. Three peduncles were united one another at the proximal end. The test is rather hard, somewhat translucent, and milky white; the anastomosing vessels (Fig. 3-13) can be seen through faintly.

The thorax is $2.2-2.4 \mathrm{~mm}$ long. Both apertures open to the exterior directly and are round in outline. The atrial aperture is always protruded considerably beyond the level of the branchial aperture. Up to twenty muscles on each side of the thorax; posterior muscles are nearly transverse, while anterior ones are oblique extending from the dorso-posterior to the ventro-anterior of the thorax. About seven muscles in the posterior half of the thorax below the level of the anus and a dozen or a little more in the anterior half. Fertilized eggs, only a single ovum in examined zooids in the present specimens, are incubated in the right peribranchial cavity near the dorso-posterior corner of the thorax. Stigmatal rows are 13 on the left and 14 on the right side when they are examined along the dorso-median line; they will increase a little when they are counted along the endostyle. Probably up to 30 stigmata in each row on respective sides. The anus is open at the level of the 9 th transverse vessel. There are eight tentacles. The ciliated groove is a simple oval opening. The dorsal languets are arranged nearly on the dorso-median line.

The abdomen is up to $1.8 \mathrm{~mm}$ long. The stomach occupies the anterior half or less of the abdomen, the surface is smooth. The hind-stomach and the midintestine are not defined. The gonad covers the whole left side of the intestinal loop, the ovary occupies the anterior to central part of the gonad, many testicular follicles are present. The vas deferens is very prominent. A vascular vessel is issued from the rear end of respective abdomens and joins to the vessel network in the peduncle. Remarks: The number of stigmatal rows in zooids from the present colonies seems to intermediate between the Philippine specimens which were examined far ago by 


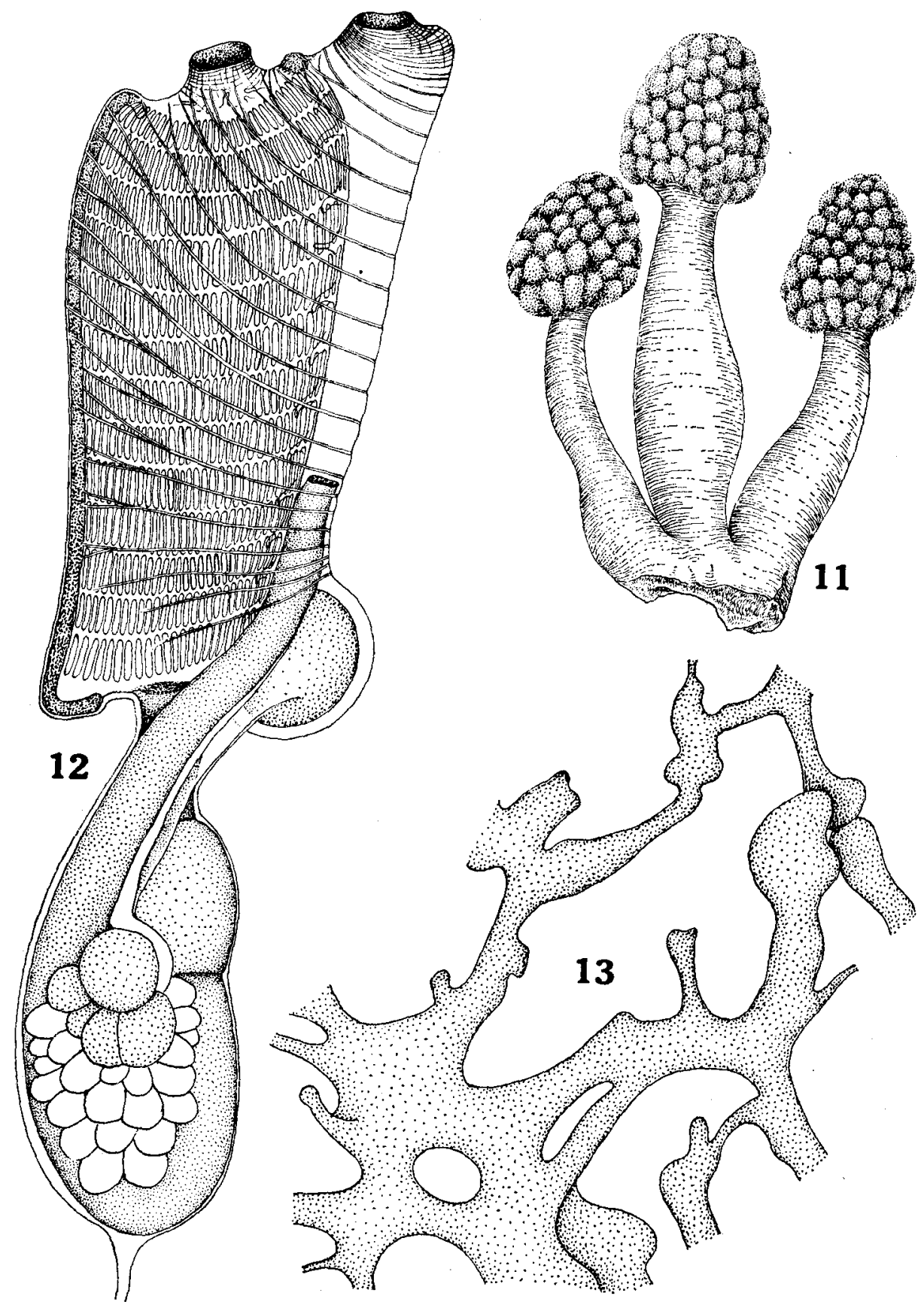
Fig. 3. Nephtheis fascicularis (DRAsche). 11-A colony, $\times$ ca. 1.6. 12-Left side of a zooid,
$\times 33 . \quad 13-$ A part of the peduncle, $\times 73$. 
VAN NAME (1918) and including zooids with 20 or more stigmatal rows and the specimen from the Arafura Sea including zooids with 11-12 stigmatal rows (TokiokA, 1952).

\section{Ascidia sydneiensis samea (OKA)}

(Fig. 4-14)

Ascidia samea-OKA (1935): Sci. Rep. Tôhoku Imp. Univ., vol. 10, no. 3, p. 461, figs. 31-32. Ascidia sydneiensis samea-ТоктокА (1953): Ascidians of Sagami Bay, p. 226; pl. 34, figs. 6-10; pl. 35, figs. 1-10; pl. 36, figs. 1-10. (1967): U.S. Nat. Mus. Bull. 251, p. 138, fig. 50.

Sp. No. 957b. A single specimen, $52 \mathrm{~mm}$ long, $31 \mathrm{~mm}$ wide, and $8 \mathrm{~mm}$ thick laterally. The surface was covered wholly by a colony of Diplosoma macdonaldi Herduan.

The animal attaches to the substratum by the whole left side. The branchial siphon subterminal, a little dorsal, and short; the atrial siphon is short, too, and situated with its anterior base at the middle of the dorsal side. The test is thin, but tough and somewhat hard to touch, hard gelatinous, milky white, translucent and the mantle body can be seen through. The mantle body is reddish brown. Transverse muscles are interrupted widely at the middle. The anterior end of the intestinal loop attains the level of the anterior base of the atrial siphon. The axis of the second intestinal loop passes through the pyloric end of the stomach. Tentacles are 64 including larger and smaller ones but excluding some minute ones intervening between the larger and smaller ones. The arrangement of - large - small - large - small - can be observed in some parts. The ciliated groove is split complicatedly (Fig. 4-14). Sixty-one inner longitudinal vessels and about 180 transverse vessels on the right side of the branchial sac. A couple of pontelid shrimps were found in the peribranchial cavity.

\section{Phallusia depressiuscula (HELleR)}

(Fig. 4, 15-22)

Ascidia depressiuscula-Herdman (1906): Rep. Ceylon Pearl Oyster Fish., Part 5, Suppl. Rep., no. 39, p. 305; pl. 2, figs. 10-22. VAN NAme (1918): U.S. Nat. Mus. Bull. 100, vol. 1, part 2, p. 116, figs. $72-74$; pl. 27 , figs. $10-13$.

Phallusia depressiuscula-Hastings (1931): Great Barrier Reef Exped., vol. 4, no. 3, p. 80, fig. 6. Tokioka (1952): Publ. Seto Mar. Biol. Lab, vol. 2, no. 2, p. 110, fig. 13.

Sp. No. 956. A single specimen $75 \mathrm{~mm}$ long, $33 \mathrm{~mm}$ wide, and 8-13 $\mathrm{mm}$ thick laterally. The animal attaches to the substratum by the left posterior side of the body. The branchial aperture terminal, open at the tip of a short stout siphon; the atrial siphon is protruded anteriorly from the middle of the dorsal side. The test is hard gelatinous, up to $2 \mathrm{~mm}$ in thickness, and grayish brown in colour; the surface is smooth and free from any foreign matters, but is marked with a few longitudinal 


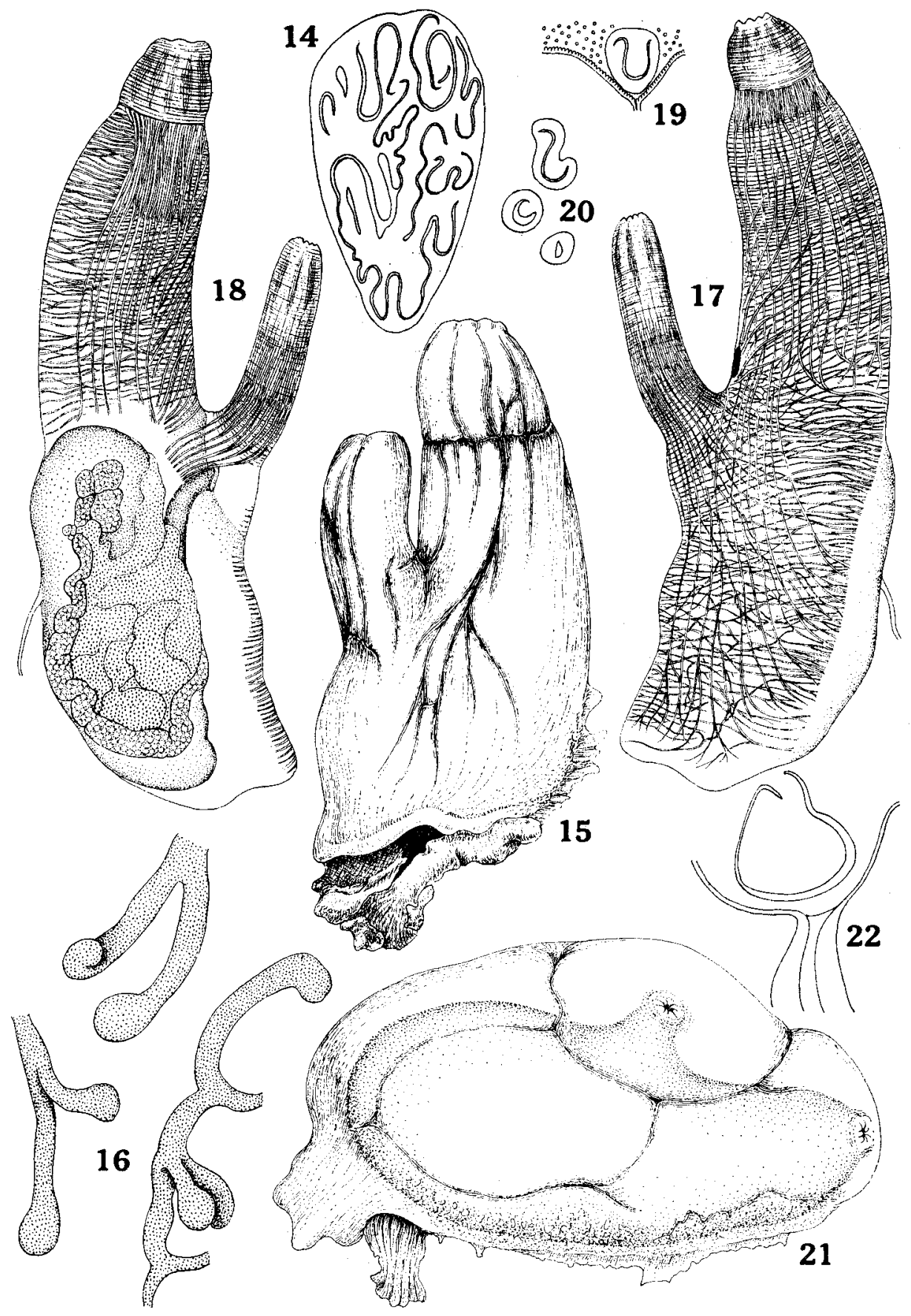

Fig. 4. 14: Ascidia sydneiensis samea (ОкA). Dorsal tubercle with split ciliated grooves. 15-20: Phallusia depressiuscula (Heller). 15-Right side of the $75 \mathrm{~mm}$ long specimen. 16-A part of the test, $\times 73$. 17-Right side of the mantle body. 18-Left side of the mantle body. 19-Dorsal tubercle, magnified. 20-Three accessory tubercles, magnified. 21, 22: ?Phallusia depressiuscula (HELLER). $21-$ Right side of the $57 \mathrm{~mm}$ long specimen. 22-Ciliated groove, magnified. 
grooves which are probably formed by contraction. There are many vessels penetrating through the test, they are ramified into many branches ending blindly, but the ramification is much simpler than in Phallusia julinea Sluiter (Fig. 4-16). The mantle body is dark purplish brown. On the mantle body (Fig. 4-17, 18), the atrial siphon is very prominent. The branchial aperture is 8 -lobed and the atrial 6-lobed. The right side is wholly reticulated with a musculature which consists of longitudinal and transverse muscles; longitudinal muscles are remarkable in the anterior half and in the dorsal portion of the posterior half. On the left side, the anterior half is very muscular, too; about a dozen longitudinal muscles are prominent there. The dorsal gangilon is situated near the anterior base of the atrial siphon. The anterior end of the intestinal loop attains the level of the anterior base of the atrial siphon. The axis of the second intestinal loop seemingly passes through the middle of the stomach. The anal margin is slightly thickened and forms irregular lobules by contraction. The vessel to the test is issued from the ventral side of the visceral mass slightly anterior to the middle of the mass.

Tentacles are about 60, the arrangement of - large - small - medium - small large - is maintained partially. The prebranchial area is papillated. The peribranchial band is furnished with a series of minute prominences along the anterior margin. The ciliated groove is simple $\mathrm{U}$-shaped, and open on a rather small tubercle. A number of accessory ciliated grooves are found between the dorsal ganglion and the proper ciliated groove, opening to the peribranchial cavity in the posterior range behind the posterior end of the right accessory lamina; they are up to 34 on the left side only. These grooves are very simple in outline (Fig. 4-20) and generally coloured yellowish. There is a remarkable right accessory lamina along the anterior oneforth of the dorsal lamina. The dorsal lamina is supported in the posterior half by strong ribs which protrude out into a finger-shaped prominence beyond the margin of the lamina. Fifty-eight inner longitudinal vessels on the left and 61 on the right side of the branchial sac near the middle. About 300 transverse vessels are counted on the right side. The papillae at crossing points between the inner longitudinal and transverse vessels are of the usual shape common to many species of Ascidia, intermediate papillae practically absent. The plications of the branchial sac conform roughly to the inner longitudinal vessels. The arrangement of transverse vessels is seemingly-133323331-, the figures show the orders of thickness. Six to 8 stigmata are found in respective intervals between plications (stigmata on the plications are excluded).

Remarks: A problematical specimen is included in the collection (Sp. No. 954). The specimen (Fig. 4-21) is roughly oval in outline, $57 \mathrm{~mm}$ long, $32 \mathrm{~mm}$ wide, 10 $13 \mathrm{~mm}$ thick laterally, and attaches to the substratum by the ventral half of the left side. The branchial aperture is terminal, and the atrial opens slightly anterior to the middle of the dorsal side. Both apertures are sessile. The test is hard gelatinous, nearly transparent, and generally thin over the mantle body, but considerably thick 


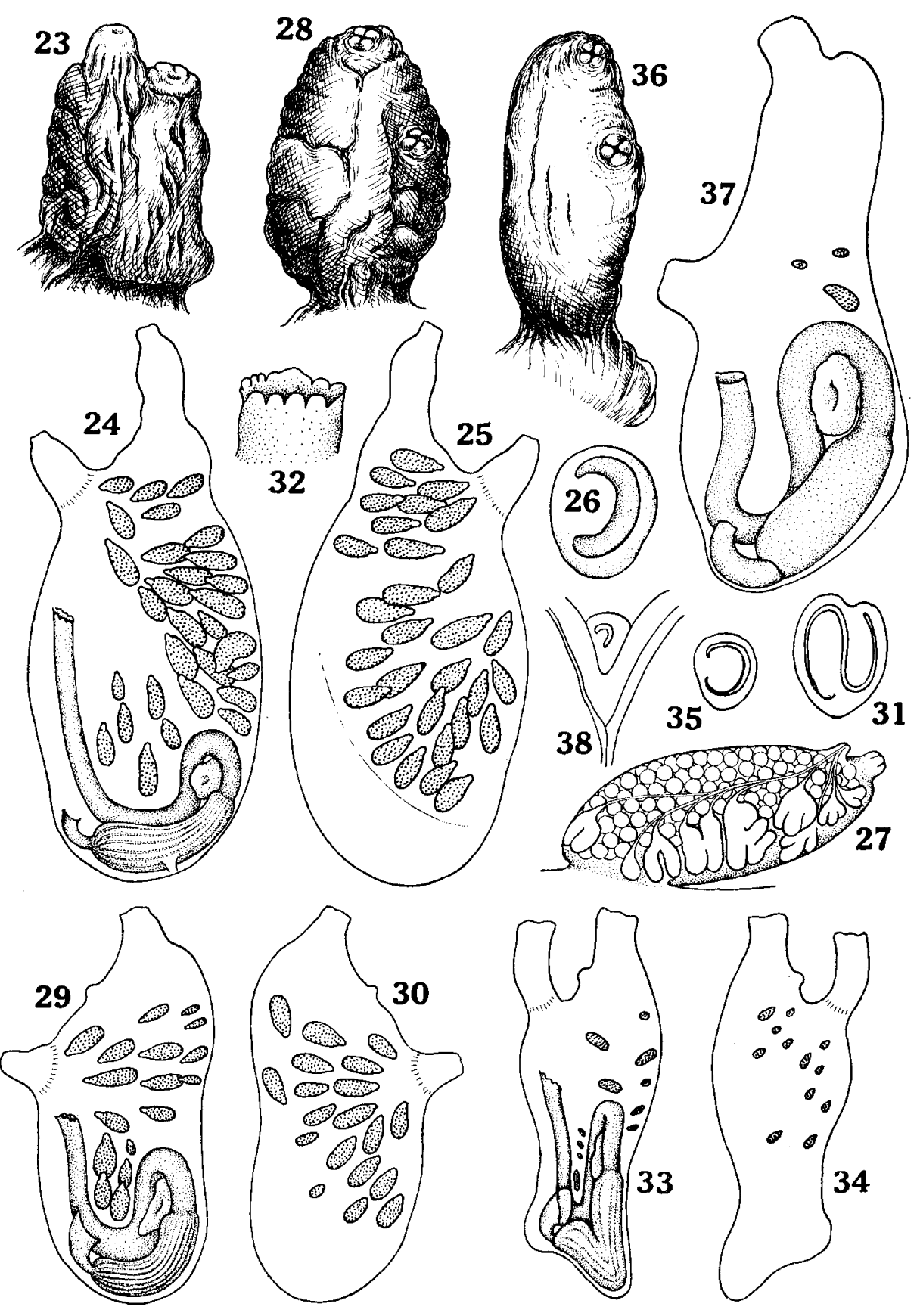

Fig. 5. Polyandrocarpa nigricans (HELlER). 23-27: A $26 \mathrm{~mm}$ long zooid. 23-Left side of the specimen. 24-Left half of the mantle body, inside. 25-Right half of the mantle body, inside. 26-Dorsal tubercle. 27-A gonadal carp. 28-32: A $20 \mathrm{~mm}$ long zooid. 28-Left side of the specimen. 29-Left half of the mantle body, inside. 30-Right half of the 
along the dorsal periphery. The surface is very smooth except for a few simple grooves and a somewhat rough appearance along the ventral periphery. The mantle body is reddish brown, seen through the test; the mantle is extremely thin. Of the musculature on the right side of the mantle body, transverse muscles are seemingly more prominent than oblique muscles which are confined to the dorsal half. The atrial siphon is distinct, but not so long, the branchial is insignificant. The branchial sac and a large part of the visceral mass are much damaged by a couple of pontelid shrimps.

Tentacles 27, including large and small ones which alternate regularly in some parts. The ciliated groove is U-shaped (Fig. 4-22). The dorsal ganglion is situated apart from the ciliated groove for about the distance seven times the ganglion length, approximately at the posterior one-third of the span between both siphons or a little more posteriorly. No accessory ciliated grooves are detected. There is a distinct right accessory dorsal lamina extending for the distance six times the diameter of the dorsal tubercle. The supporting ribs of the dorsal lamina do not extend beyond the free margin of the lamina. About 65 inner longitudinal vessels near the anterior end of the right side of the branchial sac, and about 240 transverse vessels. Plications insignificant, 3-4 stigmata in a mesh. The further details of the structure cannot be studied because of the damage done by parasitic shrimps. This specimen seems to be an individual of $P h$. depressiuscula, because the dorsal ganglion is situated much posteriorly for the species of the genus Ascidia. However, the absence of accessory ciliated grooves and somewhat different appearance of the mantle musculature present some question about this identification. It is not impossible that the specimen is a species of the genus Ascidia, possibly Ascidia gemmata Sluiter.

\section{Polyandrocarpa nigricans (HELLER)}

(Fig. 5)

Polycarpa nigricans-HARTMeYer (1905): Zool. Jahrb., Suppl. 8, p. 390; pl. 13, figs. 1, 12-14.

Sp. No. 959b.-More than twenty individuals completely fused one another to form a mass wrapping round two specimens of Polycarpa cryptocarpa (Sluiter). Sp. No. 960.- Two masses, consisting respectively of 3 and 7 individuals.

The individuals are up to $26 \mathrm{~mm}$ in length. The fusion of the test between individuals is so complete that individuals can never be separated from one another. The masses, therefore, are better treated here as colonies and individuals may better be called zooids. Zooids are roughly oval in outline; usually attach to one another by the posterior end. The branchial aperture is terminal and the atrial is situated

mantle body, inside. 31-Dorsal tubercle. 32-Anus. 33-35: A $15 \mathrm{~mm}$ long zooid. 33Left half of the mantle body. 34-Right half of the mantle body. 35-Dorsal tubercle. 36-38: Another $15 \mathrm{~mm}$ long zooid. 36-Left side of the specimen. 37-Left half of the mantle body, inside. 38-Dorsal tubercle. 
near it or near the middle of the dorsal side. Siphons are insignificant on the test surface. The test is soft leathery or gelatinous, dark purplish brown, rather thick, 1-2 mm even in smaller zooids. The surface is generally smooth, but often grooved irregularly, most frequently longitudinally. The inner surface is a little lighter.

The mantle body is dark brownish purple. The branchial siphon terminal, the atrial siphon near the branchial to the middle of the dorsal side; both siphons are distinct. The mantle surface is sometimes scattered with a number of irregularly shaped white spots up to $80 \mu$ across or with many minute dark roundish bodies about $125 \mu$ in diameter. There are many colourless spherules up to $70 \mu$ in diameter on the inner mantle surface, but no endocarps except for a large one in the first intestinal loop. Fine atrial tentacles are present. The branchial tentacles are 22 to 30 , larger and smaller ones alternate rather regularly. The ciliated groove is usually C-shaped, but sometimes it assumes a S-shape. The inner longitudinal vessels are arranged as follows:

$13 \mathrm{~mm}$ long mantle body

$\begin{array}{llllllllllll}\text { Left } & \mathrm{D} & 0 & (7) & 2 & (7) & 2 & (9) & 2 & (7) & 1 & \mathrm{~V} \\ \text { Right } & \mathrm{D} & 0 & (9) & 2 & (6) & 2 & (8) & 2 & (7) & 1 & \mathrm{~V}\end{array}$

$14 \mathrm{~mm}$ long mantle body

$\begin{array}{lllrrrrrrrrr}\text { Left } & \mathrm{D} & 0 & (9) & 2 & (9) & 2 & (11) & 2 & (9) & 1 & \mathrm{~V} \\ \text { Right } & \mathrm{D} & 0 & (11) & 2 & (10) & 2 & (11) & 1 & (8) & 1 & \mathrm{~V}\end{array}$

$20 \mathrm{~mm}$ long mantle body

$\begin{array}{llrrrrrrrrrr}\text { Left } & \mathrm{D} & 0 & (9) & 2 & (10) & 2 & (12) & 2 & (9) & 1 & \mathrm{~V} \\ \text { Right } & \mathrm{D} & 0 & (11) & 2 & (8) & 2 & (11) & 2 & (8) & 2 & \text { V }\end{array}$

$21 \mathrm{~mm}$ long mantle body

$\begin{array}{lllrrrrrrrrr}\text { Left } & \mathrm{D} & 0 & (9) & 2 & (9) & 3 & (11) & 2 & (9) & 2 & \mathrm{~V} \\ \text { Right } & \mathrm{D} & 0 & (11) & 2 & (9) & 2 & (9) & 2 & (10) & 2 & \mathrm{~V}\end{array}$

No accessory plications are found on the sac wall. Transverse vessels are arranged as -thick thin thick thin- or - thick thin medium thin thick-; parastigmatic vessels practically absent; 5-6 to 9-10 stigmata in a mesh, up to 13-15 stigmata in meshes along the endostyle.

The alimentary canal forms two remarkable loops. The stomach is elongate, occupies about two-thirds of the ventral branch of the first loop and is marked with about six longitudinal plications on the free surface. A large endocarp is included in the loop. The second intestinal loop is very distinct, deep, but much wider than the first loop; the axis passes through near the middle of the stomach. In zooids, in which the atrial siphon is issued from near the branchial siphon, the rectum may be much elongated (Fig. 5-24). The anal margin is irregularly lobed.

The gonads are not yet well developed in 13 and $14 \mathrm{~mm}$ long mantle bodies. While, in 20 and $21 \mathrm{~mm}$ long mantle bodies, many gonadal carps are found. Each gonad (Fig. 5-27) is roughly ovoid in shape, up to $2 \mathrm{~mm}$ in length, and attaches to 
the inner surface of the mantle by the posterior one-third to one half of the gonad length. Complicatedly lobated testicular follicles are roughly arranged in two rows on the side of attachment. Mature eggs are about $170 \mu$ in diameter. The male genital aperture opens near the terminal opening of the ovary. Up to 30 gonads on each side.

Remarks: In the specimens from Mauritius examined by HARTMEYER, the inner longitudinal vessels between the branchial plications are 3-4, a little more than in the present specimens. This difference, however, does not seem significant to object to the present identification.

\section{Polycarpa aurata (QUOY et GAIMARD)}

(Fig. 6)

Styela aurata-SLUITER (1904): Siboga-Exped., 56a, p. 57.

Pandocia aurata -VAn NAme (1918): U.S. Nat. Mus. Bull. 100, vol. 1, part 2, p. 94; pl.25, figs. 5-6; text-figs. 47-48.

Polycarpa aurata Sluiter (1919): Bijd. Dierk., afl. 21. p. 3. Tokroka (1967): U.S. Nat. Mus. Bull. 251, p. 169, fig. 68.

Polycarpa sulcata-Drasche (1884): Denkschr. Akad. Wiss. Wien, vol. 48, p. 379; pl. 6, fig. 12; pl. 7, figs. 1--2, 2a. Michaelsen (1905): Zool. Jahrb. Suppl., vol. 8, p. 97.

For others see Tокіока (1967).

Sp. No. 951. Two specimens, respectively $70 \mathrm{~mm}$ long $\times 40 \mathrm{~mm}$ wide and $35 \mathrm{~mm}$ long $\times 22 \mathrm{~mm}$ wide. The width measured in the range from the middle to near the posterior end, excluding the attachment process.

The body is oval (smaller specimen, Fig. 6-43) to somewhat elongate (larger specimen, Fig. 6-39), attaches to the substratum by the ventral side, near the middle in the smaller and in the posterior one-third in the larger specimen. In larger individuals, the posterior part of the body is usually a little turned dorsads. The branchial aperture terminal, the siphon insignificant; the atrial at the middle of the dorsal side, the siphon distinct, though very short. The test is soft leathery, light grayish brown, somewhat darker around the site of attachment. The surface is smooth and free from any foreign materials, marked with one or two deep longitudinal grooves. It is $2-4 \mathrm{~mm}$ in thickness, especially thickened in the posterior half of the larger specimen. The inner surface of the test is white to grayish white, very soft or rather gelatinous. The mantle body is $55 \mathrm{~mm}$ and $29 \mathrm{~mm}$ long respectively, dark orange brown to purplish brown, the same dark colouration is seen also on the branchial sac and the alimentary canal. Both siphons are remarkable, coloured more darkly. The inner surface is a little lighter, usually orange brown, and is provided with many endocarps over the whole surface. Fine atrial tentacles are present.

Twenty-four (smaller specimen) to 30 (larger specimen) branchial tentacles, including large and small ones, but excluding minute ones which may be seen in 


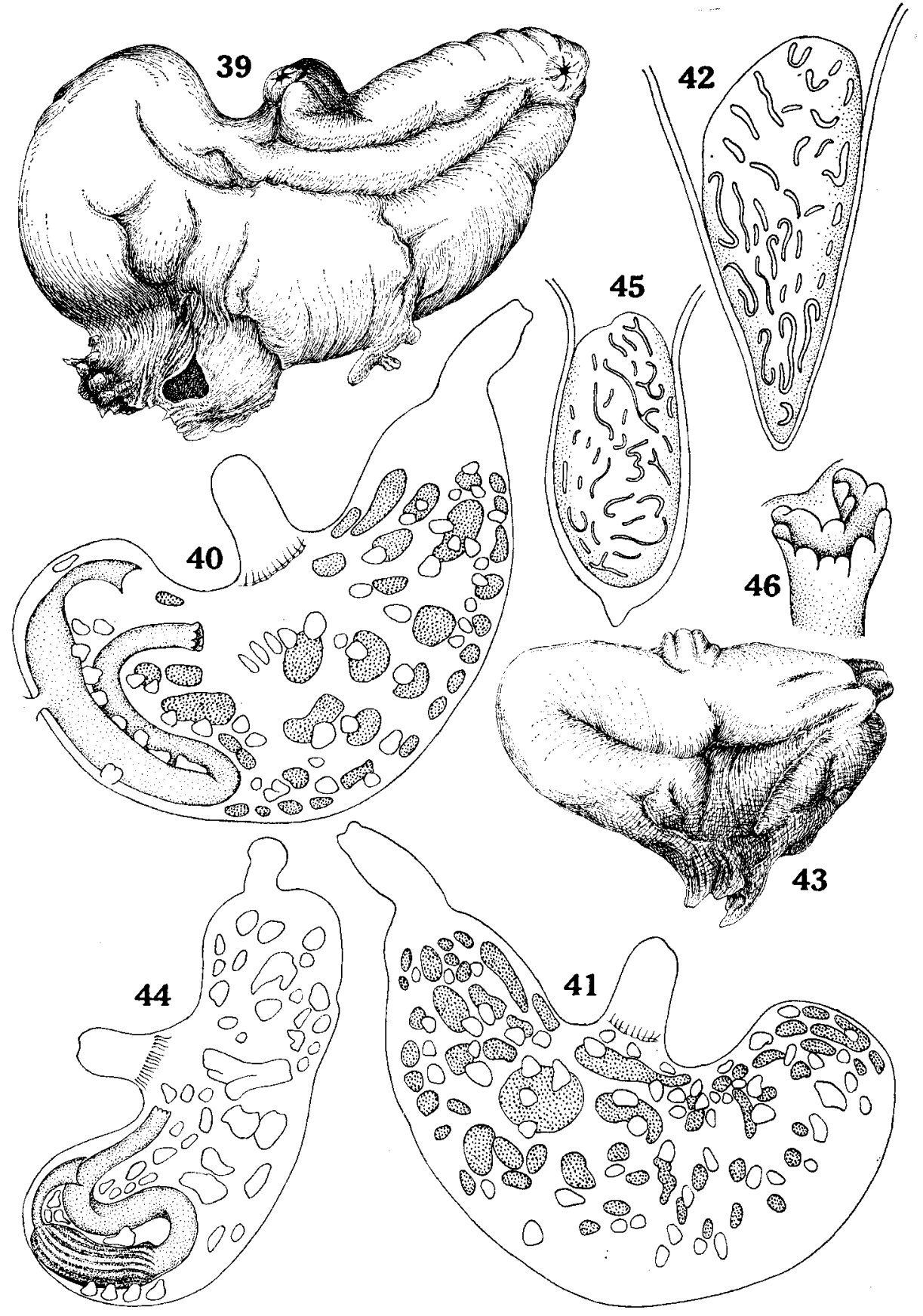

Fig. 6. Polycarpa aurata (Quoy et Gaimard). 39-42: The $70 \mathrm{~mm}$ long individual. 39 - Right side of the specimen. 40-Left half of the mantle body, inside. 41-Right half of the mantle body, inside. 42-Dorsal tubercle. 43-46: The $35 \mathrm{~mm}$ long individual. 43-Right side of the specimen. 44 Left half of the mantle body, inside. 45-Dorsal tubercle. 46-Anus. 
some intervals between the large and small tentacles. The ciliated groove is cut into a number of small pieces. The inner longitudinal vessels are arranged near the middle as follows.

$29 \mathrm{~mm}$ long mantle body

$\begin{array}{llllllllllll}\text { Left } & \mathrm{D} & 4 & (13) & 5 & (15) & 4 & (18) & 4 & (10) & 2 & \mathrm{~V} \\ \text { Right } & \mathrm{D} & 2 & (18) & 3 & (18) & 4 & (13) & 5 & (13) & 4 & \text { V }\end{array}$

$55 \mathrm{~mm}$ long mantle body

$\begin{array}{llllllllllll}\text { Left } & \mathrm{D} & 4 & (19) & 6 & (22) & 5 & (20) & 6 & (16) & 8 & \mathrm{~V} \\ \text { Right } & \mathrm{D} & 1 & (26) & 5 & (23) & 5 & (21) & 6 & (16) & 6 & \mathrm{~V}\end{array}$

Transverse vessels are arranged as -133323331 - or -13231-, where figures show the orders of thickness; parastigmatic vessels absent; 6-10 stigmata in each mesh. The alimentary canal forms double loops; the second loop is distinct but the depth differs a little individually, the axis passes through the cardiac to middle part of the stomach. The stomach is very elongate; in smaller specimen it occupies about two-thirds of the ventral branch of the first intestinal loop and is marked faintly with about 6 longitudinal plications on the free surface, while in the larger specimen it diminishes the thickness posteriorly gradually so that the pyloric end is quite obscure. The anal margin forms 10-12 irregularly shaped lobules.

In the smaller specimen, endocarps and rudimentary gonadal carps can hardly be strictly separated from each other. In the larger specimen, 55 gonadal carps on the left and 35 ones on the right side. The gonads are completely buried in the mantle, but the mantle is very thin above the gonad and the surface is raised a little; the structure is seen through distinctly. Smaller gonadal carps are about $0.8 \mathrm{~mm}$ in diameter and with a simple stelloid cluster of testicular follicles, while larger ones are up to $5.5 \mathrm{~mm}$ in diameter and provided with a dozen clusters of testicular follicles; this appearance reminds us of a colony of Botryllus.

\section{Polycarpa cryptocarpa (SLUITER)}

(Fig. 7)

Styela cryptocarpa-SLuiter (1885): Natuurk. Tijdschr. Nederl. -Indië, vol. 45, p. 210; pl. 2, fig. 1; p.1 7, figs. 1-3.

Polycarpa cryptocarpa-Tокгока (1967): U.S. Nat. Mus. Bull. 251, p. 173, fig. 71.

For others see Токіока (1967).

Sp. No. 959.- Two individuals, gathered together by a colony of Polyandrocarpa nigricans (Heller) consisting of about 20 zooids; $50 \mathrm{~mm}$ long $\times 24 \mathrm{~mm}$ wide and $45 \mathrm{~mm}$ long $\times 24 \mathrm{~mm}$ wide respectively.

The larger individual was dissected for identification. The body is roughly oval, a little compressed laterally, and attaches to the substratum by the right posterior side. Both siphons are distinct, though not so long. The branchial siphon 


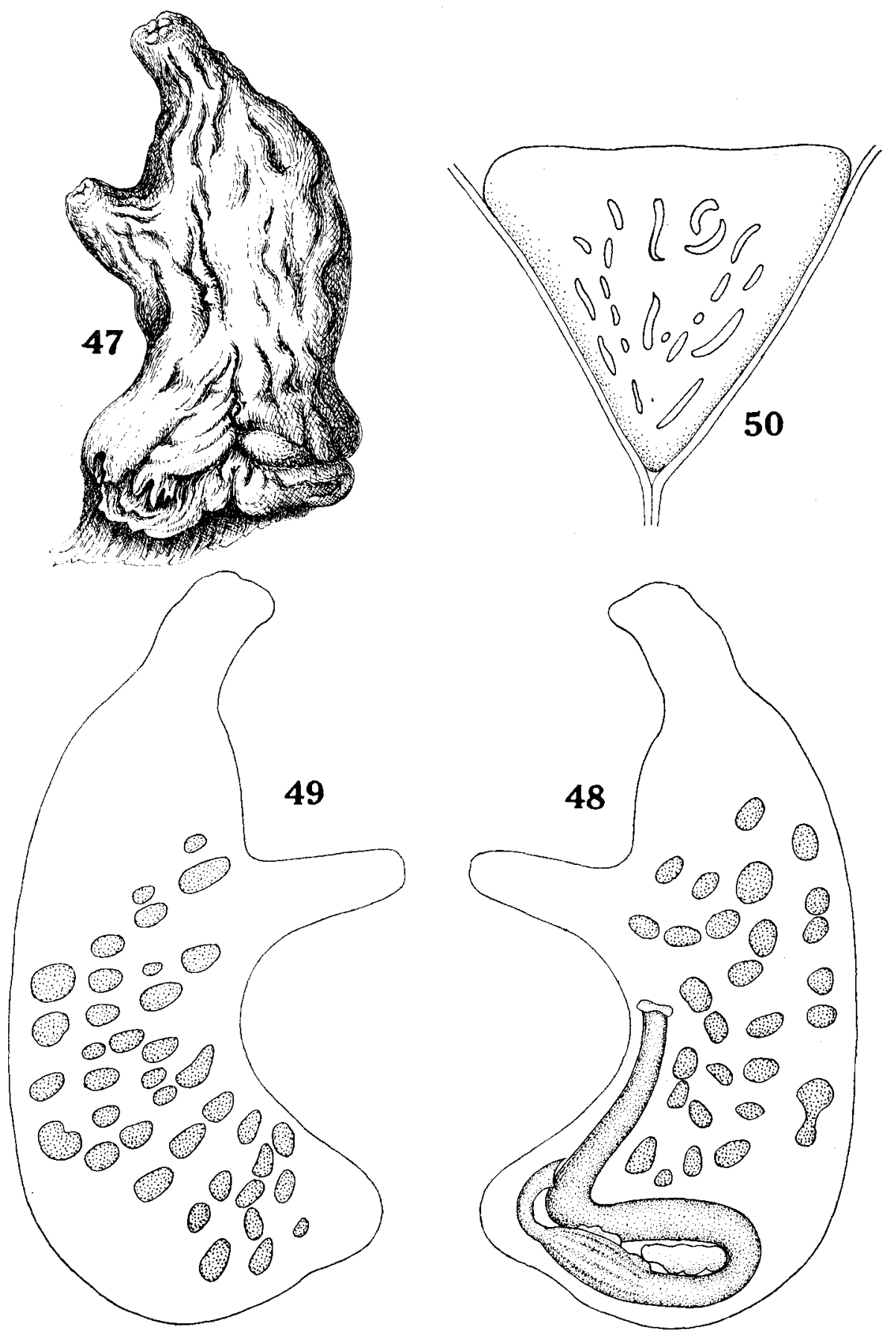

Fig. 7. Polycarpa cryptocarpa (SLUITER). 47-A $50 \mathrm{~mm}$ long individual, right side. 48-Left half of the mantle body, inside. 49-Right half of the mantle body, inside. 50-Dorsal tubercle. 
is terminal, slightly turned dorsads; the atrial is situated with the posterior base at the middle. The test is leathery, not very hard but tough enough. It is dark purplish brown to dark purplish gray, irregularly grooved on the surface, only in the distal part of siphons the surface is smooth. It is $2-3 \mathrm{~mm}$ in thickness, the inner surface is a little paler. The mantle is purplish black. The inner surface is dark purplish brown, the same colouration on the branchial sac and the alimentary canal. A number of minute dark brownish or black spots, 50-80 $\mu$ across, are distributed over both the outer and inner surfaces. No endocarps are seen on the inner surface, except for two, one larger and the other much smaller, in the first intestinal loop. Forty-four branchial tentacles, 11 large, 11 medium, and 22 small ones; they are arranged as - large small medium small large-. The ciliated groove is cut into pieces on the $1.2 \mathrm{~mm}$ long dorsal tubercle. The inner longitudinal vessels of the branchial sac are arranged near the middle as follows.

$50 \mathrm{~mm}$ long individual

$\begin{array}{llllllllllll}\text { Left } & \mathrm{D} & 1 & (8) & 3 & (13) & 5 & (12) & 5 & (8) & 4 & \mathrm{~V} \\ \text { Right } & \mathrm{D} & 2 & (11) & 3 & (11) & 4 & (12) & 4 & (9) & 4 & \mathrm{~V}\end{array}$

There is no accessory plication. Transverse vessels are generally arranged as 133323331 - the figures show the orders of thickness; parastigmatic vessels absent. Six to 8 elongate stigmata in a mesh in the middle portion.

The stomach is elongate and occupies about a half of the ventral branch of the first intestinal loop; its inner pyloric corner is marked with a slight translucent swelling. The second intestinal loop is open wide, the axis passes through the cardiac one-third. The rectum is relatively long. The anal margin is thickened. The gonads are buried deep in the mantle, quite invisible from the surface, but they are recognizable distinctly when the mantle is held to shut the light. Thirty-eight gonads on the left and 28 gonads on the right side.

\section{Polycarpa iwayamae ToKIOKA}

(Fig. 8)

Polycarpa iwayamae-Tokioka (1950): Publ. Seto Mar. Biol. Lab., vol. 1, no. 3, p. 143, fig. 18. (1967): U.S. Nat. Mus. Bull. 251, p. 174, fig. 72.

Sp. No. 950.-A single specimen, $70 \mathrm{~mm}$ long, $45 \mathrm{~mm}$ wide, $25 \mathrm{~mm}$ thick laterally; collected at Boaya Point.

Sp. No. 947.-A single specimen, $55 \mathrm{~mm}$ long, $27 \mathrm{~mm}$ wide, $18 \mathrm{~mm}$ thick laterally; collected near the Sand Bar.

The larger specimen is roughly oval, dark brownish in colour, and attaches to the substratum by the right posterior side. In the smaller specimen, the body proper is dark brownish gray, and roughly oval in shape, too, but it is provided with a wide peduncular portion; and the animal attaches to the substratum by the posterior end 
of this portion (Fig. 8-54). The branchial aperture is nearly terminal, and the atrial is situated near it; both siphons are insignificant. The test is leathery, rough to touch, rather soft at least in the smaller specimen, and $1 \mathrm{~mm}$ (smaller specimen) to $3 \mathrm{~mm}$ (larger specimen) in thickness, especially much thickened in the posterior
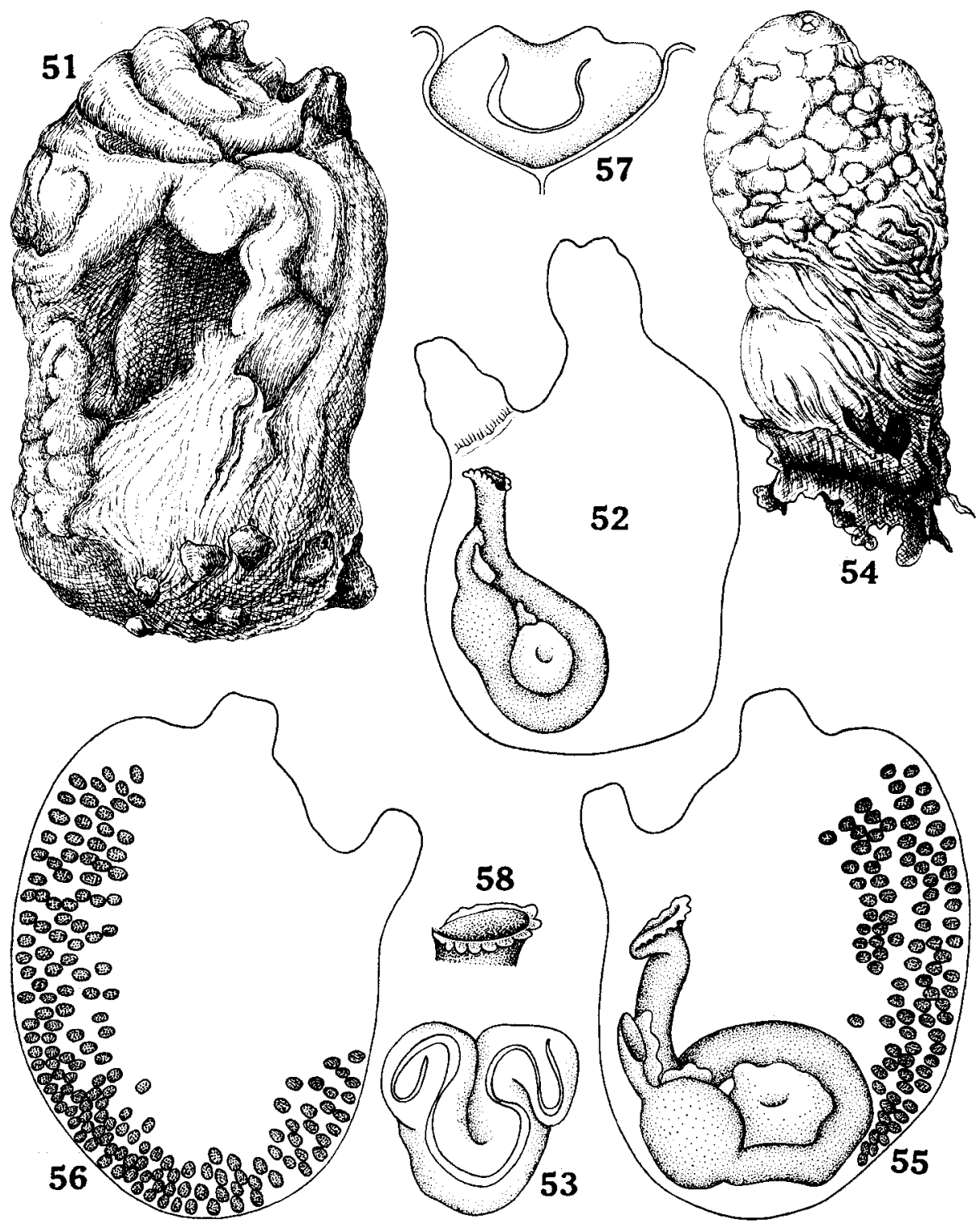

Fig. 8. Polycarpa iwayamae Токіока. 51-53: The $70 \mathrm{~mm}$ long individual. 51-Left side of the specimen. 52-Left half of the mantle body, inside. 53-Dorsal tubercle. 54-58: The $55 \mathrm{~mm}$ long individual. 54-Left side of the specimen. 55-Left half of the mantle body, inside. 56-Right half of the mantle body, inside. 57-Dorsal tubercle. 58-Anus. 
portion. The surface is corrugated by irregularly formed grooves; in the smaller specimen, however, the posterior portion is rather creased transversely. The inner surface is whitish-milky white or grayish white, somewhat translucent, and rather soft.

The mantle body is $49 \mathrm{~mm}$ long in the larger specimen and $32 \mathrm{~mm}$ long in the smaller specimen. The mantle is dark purplish brown, up to $2 \mathrm{~mm}$ in thickness in the larger specimen, but very soft. The inner side is somewhat translucent and devoid of endocarps except for one large and two much smaller ones in the first intestinal loop. Fine atrial tentacles are present. Both siphons are distinct but not long.

Branchial tentacles are 30-36 excluding a few minute ones, large and small ones alternate regularly in some parts. The ciliated groove is $\mathrm{U}$-shaped, with horns curled in or out in larger specimens. The branchial sac is pale purplish brown. The inner longitudinal vessels are arranged as follows.

$32 \mathrm{~mm}$ long mantle body

$\begin{array}{llllllllllll}\text { Left } & \mathrm{D} & 2 & (9) & 2 & (13) & 3 & (13) & 4 & (11) & 4 & \mathrm{~V} \\ \text { Right } & \mathrm{D} & 3 & (9)^{*} & 3 & (13) & 3 & (13) & 3 & (12) & 3 & \mathrm{~V}\end{array}$

* In the posterior part, there occurs a weak accessory plication between the dorsal lamina and the first fold as D 1 (3) $1(9)^{*}$

$49 \mathrm{~mm}$ long mantle body

$$
\begin{array}{lrrrrrrrrrrrrr}
\text { Left } & \mathrm{D} & 3 & (11) & 7 & (16) & 6 & (16) & 7 & (15) & 6 & \mathrm{~V} & & \\
\text { Right } & \mathrm{D} & 0 & (4) & 2 & (15) & 5 & (17) & 7 & (16) & 6 & (13) & 6 & \text { V }
\end{array}
$$

Transverse vessels are arranged as -133323331-, the figures show the orders of thickness, parastigmatic vessels practically absent. Six to $8 \sim 10$ to 12 stigmata in a mesh, up to 18 in meshes along the endostyle. The second intestinal loop is seemingly insignificant in the normal state (Fig. 8-52); when the second loop is formed (Fig. 8-55) the axis passes through the cardiac end of the stomach which is globular in outline. The anal margin is furnished with 9-15 lobules.

No gonads are found in the larger specimen. In the smaller specimen, 161 gonads on the left and 92 ones on the right side. They are rather small, confined to the ventral half, and are buried completely in the mantle, but clearly visible through the mantle which is very thin and transparent above the gonads.

\section{Polycarpa papillata (Sluiter)}

(Fig. 9)

Slyela papillata-SLurter (1885): Natuurk. Tijdschr. Ned. -Ind., vol. 45, p. 192; pl. 1, fig. 8; pl. 5, figs. 1-4. (1891): Natuurk. Tijdschr. Ned. -Ind., vol. 50, p. 333.

Polycarpa papillata-TokıкA (1952): Publ. Seto Mar. Biol. Lab., vol. 2, no. 2, p. 117, fig. 17.

Sp. No. 952.-A single specimen, $55 \mathrm{~mm}$ long, $29 \mathrm{~mm}$ wide, and $15 \mathrm{~mm}$ thick laterally; collected at Boaya Point. 
The body is elongate, with a prominent process near the middle of the dorsal side, and attaches to the substartum by the posterior end. The branchial aperture opens at the terminal and the atrial at the tip of the middle prominence. The test is leathery, very hard, grayish yellow white in most parts, but dark reddish brown in the areas around and between both apertures. The surface is generally smooth, carries no foreign materials, and is furnished with a few irregular grooves formed by contraction. It is $2-3 \mathrm{~mm}$ in thickness. The inner surface of the test is generally grayish white and glistening, though it is dark reddish brown around and between the apertures.

The mantle body is $47 \mathrm{~mm}$ long, including the $9 \mathrm{~mm}$ long branchial siphon which is extended straight anteriorly. The atrial siphon is short, but very thick, situated with the posterior base at the middle of the body. The mantle is grayish white, siphons and the area between them are light pinkish. The site of the dorsal ganglion is remarkably protruded at the anterior one-third of the distance between siphons. This and the appearance of the atrial siphon are evidently brought about by the strongly developed mantle musculature. The atrial siphon is wholly covered with circular muscles, whereas other parts of the body are generally covered with strong transverse muscles (Fig. 9-60). A sudden contraction of this strong musculature must have caused the evisceration from the branchial aperture, which is seen on this specimen. The inner surface of the mantle is furnished all over with many endocarps which are all elongate in shape. There are fine atrial tentacles.

The branchial tentacles are 32 including larger and smaller ones which alternate rather regularly. The ciliated groove is $\mathrm{S}$-shaped. The inner longitudinal vessels of the branchial sac are arranged as follows.

$\begin{array}{llllllllllll}\text { Left } & \mathrm{D} & 3 & (18) & 4 & (17) & 3 & (18) & 4 & (20) & 0 & \mathrm{~V} \\ \text { Right } & \mathrm{D} & 4 & (17) & 4 & (20) & 3 & (22) & 3 & (23) & 0 & \mathrm{~V}\end{array}$

Transverse vessels are arranged as -1 p 3 p 2 p 3 p 1 , where the figures show the orders of thickness and $\mathrm{P}$ represents the parastigmatic vessel; up to 8 stigmata in a mesh. There are a pair of low laminae on the dorsomedian line of the sac.

The stomach is elongate, the second intestinal loop is almost insignificant as it is extremely shallow. The rectum is relatively long, the anal margin is furnished with a number of lobules, two of which are unusually very elongated (Fig. 9-64).

Gonadal carps are 8 on the right and 9 on the left side, they are elongate, attach to the mantle surface very weakly and so are very easily detachable, and arranged roughly in a row stretched antero-posteriorly.

Remarks: The inner longitudinal vessels of the branchial sac seem a little more in the present specimen than in the specimens ever reported from the Arafura Sea (ToкıокA, 1952), probably this is because the vessels were counted in the present specimen in the limited part of the ejected branchial sac, which was far apart from the middle part that was unavailable in an eviscerated state. 


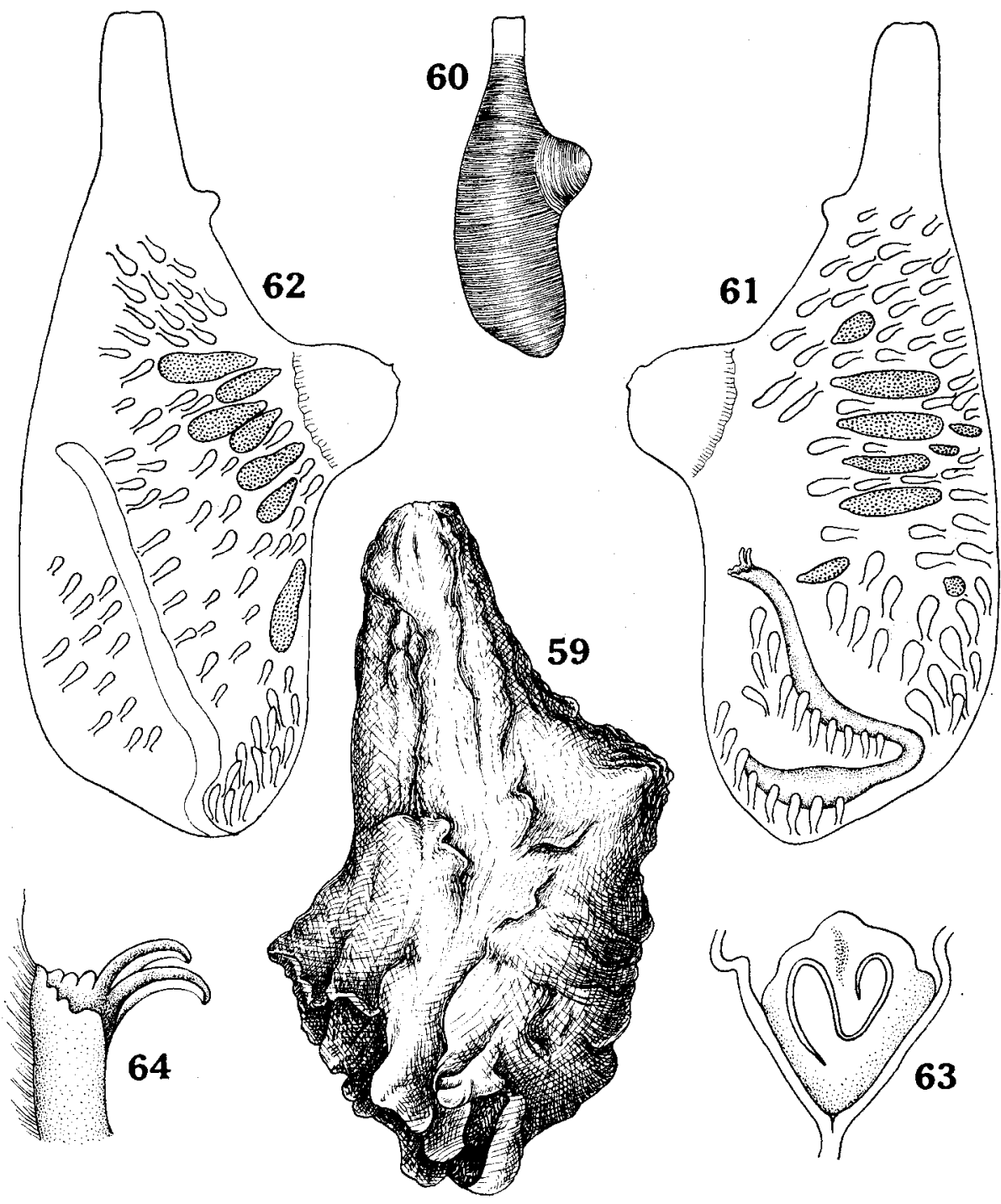

Fig. 9. Polycarpa papillata (Sluiter). 59-Left side of the $55 \mathrm{~mm}$ long specimen. 60-Left side of the mantle body. 61-Left half of the mantle body, inside. 62 -Right half of the mantle body, inside. 63-Dorsal tubercle. 64-Anus.

\section{Polycarpa cylindrocarpa n. sp.}

(Fig. 10)

Sp. No. 949.-A single specimen, $60 \mathrm{~mm}$ long and $33 \mathrm{~mm}$ wide, collected at Boaya Point.

The animal forms an elongate mass, with the branchial aperture at the terminal 
and the atrial aperture near the middle of the dorsal side; both apertures are nearly sessile. A large mass of excess test substance attaches to the left anterior side of the body; this might probably have developed to envelope some organism which has,

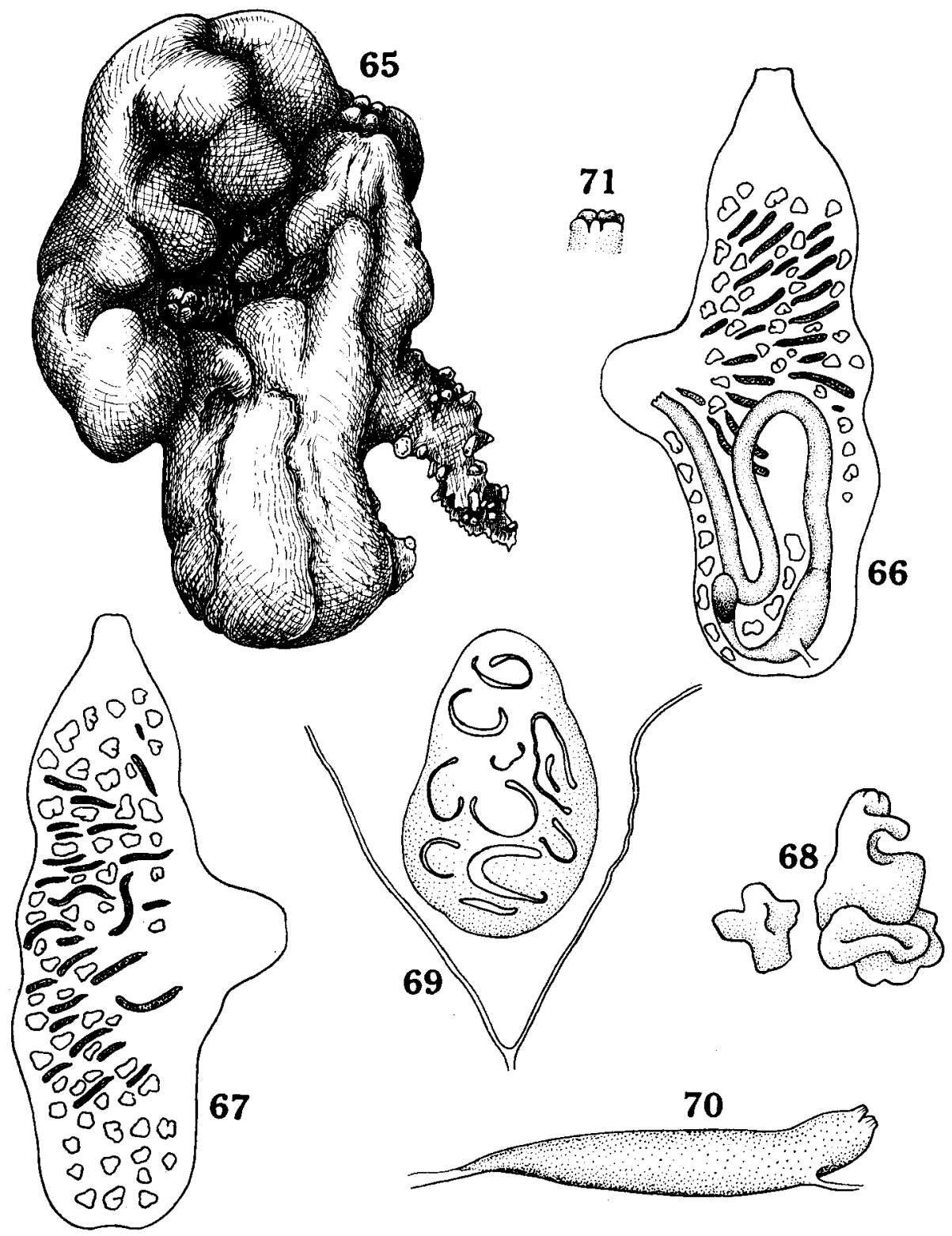

Fig. 10. Polycarpa cylindrocarpa n. sp. $65-$ The $60 \mathrm{~mm}$ long specimen, right side, 66-Left half of the mantle body, inside. 67-Right half of the mantle body, inside. 68-Two endocarps, enlarged. $69-$ Dorsal tubercle, $\times 33$. 70-A gonad, $\times 20.71-$ Anus. 
however, already disappeared within the mass (Fig. 10-65). The animal seemingly attaches to the substratum by the whole left side. The test is hard leathery, dark brownish in colour, and the surface is marked with a few irregularly formed longitudinal grooves. It is up to $3 \mathrm{~mm}$ in thckness; the section and the inner surface are grayish white, except for both siphonal areas which are reddish.

The mantle is thick, purplish brown in colour, and provided on the inner surface with many endocarps which are of a complicated configuration but never simply elongate in shape (Fig. 10-68). The atrial siphon is short, but very wide.

About 20 stout branchial tentacles are present. The ciliated groove is split into about a dozen pieces on the tubercle $1.1 \mathrm{~mm}$ in length (Fig. 10-69). The branchial sac is coloured brownish. The inner longitudinal vessels are arranged as follows.

$\begin{array}{llllllllllll}\text { Left } & \text { D } & 3 & (27) & 4 & (17) & 5 & (20) & 4 & (12) & 4 & \text { V } \\ \text { Right } & \text { D } & 5 & (25) & 4 & (21) & 4 & (17) & 5 & (13) & 4 & \text { V }\end{array}$

About seven thinner transverse vessels between each pair of thicker ones, no parastigmatic vessels are seen, up to 8 stigmata in a mesh.

The alimentary canal forms two deep loops. The first loop is very large, with the anterior end of the loop at the level of the anus and the atrial aperture; the stomach is elongate, thin, and occupies only less than one half of the ventral branch of the first loop. The second loop is very deep, the axis passes through the cardiac end of the stomach. The anus is surrounded by several lobules.

The gonadal carps are 27 on the right and 23 on the left side, distributed evenly all over respective sides; they are very elongate, cylindrical, attaining $2.5 \mathrm{~mm}$ in length, held on the mantle surface by two short and thin trabeculae respectively issued from the posterior end and from near the anterior end (Fig. 10-70), thus they are very easily detached from the surface.

Remarks: This new species resembles Polycarpa circumalata (Sluiter), Polycarpa melanosiphonica Tokioka, and Polycarpa papillata (Sluiter) in the general structures of the test body and the mantle body. However, the present new species is unique in having the ciliated groove split complicatedly. From $P$. papillata, it differs in the shape of the endocarps and the appearance of the alimentary canal. In $P$. circumalata. the gonads are buried in the mantle, the stomach is oval, and the second intestinal loop is indistinct. In P. melanosiphonica, the gonads are roundish in outline, the endocarps are simply elongate in shape, and the second intestinal loop is insignificant.

\section{Pyura sp. aff. lignosa MiChAELSEN}

(Fig. 11)

Pyura lignosa-Michaelsen (1908): Jahrb. Wiss. Anst. Hamburg, vol. 25, Suppl. 2, p. 256; pl. 1, fig. 9; pl. 2, figs. 20-21. Van Name (1945): Bull. American Mus. Nat. Hist., vol. 84, p. 336, fig. 222. 
Sp. No. 959a.-A single specimen from the body surface of Polycarpa cryptocarpa (SLuiter); $4.1 \mathrm{~mm}$ long, $3.2 \mathrm{~mm}$ wide, and about $2 \mathrm{~mm}$ high.

The animal is roughly oval in outline, attaches to the substratum by the whole

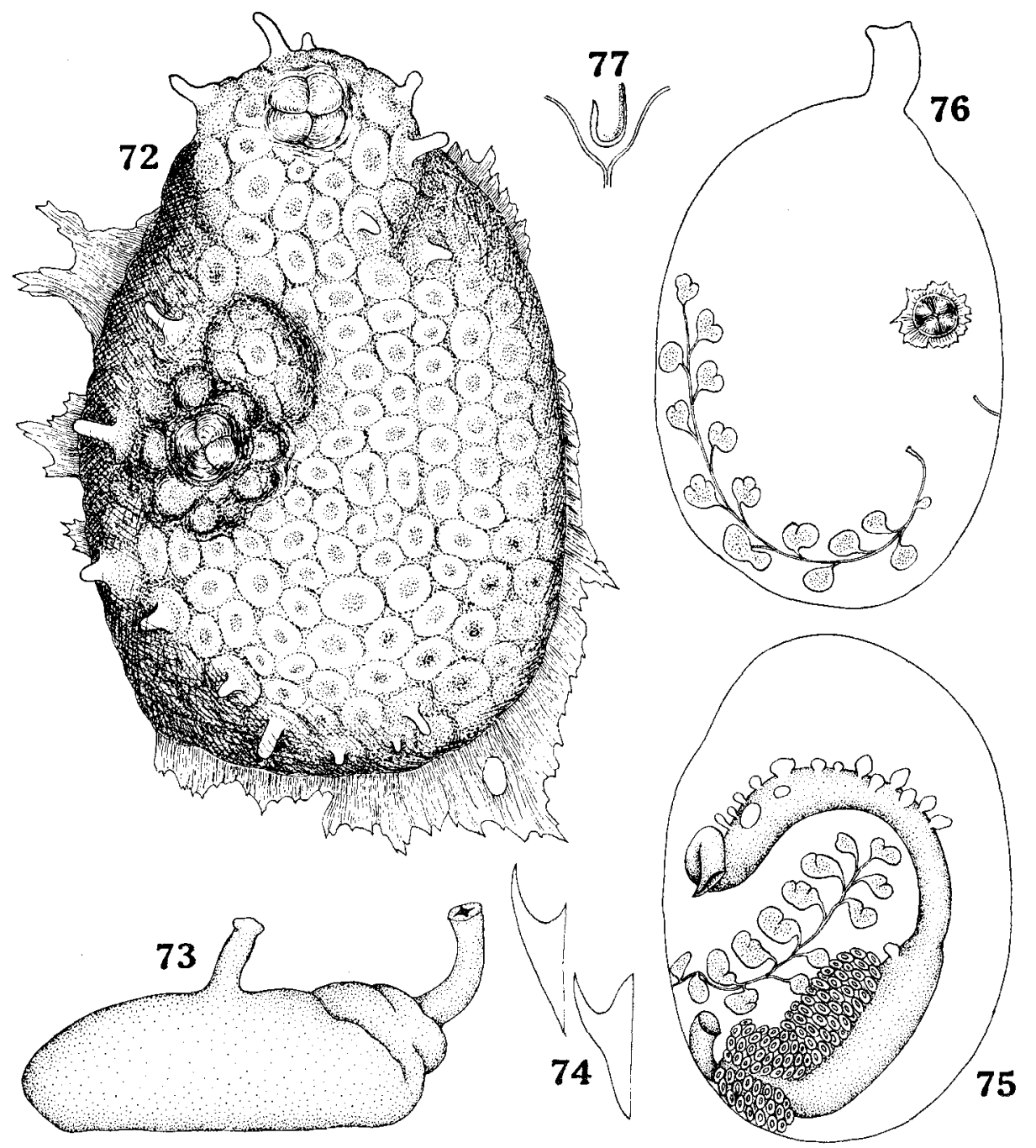

Fig. 11. Pyura sp. aff. lignosa Mrchaelsen. 72-The $4.1 \mathrm{~mm}$ long specimen, dorsal. 73-Right side of the mantle body. $74-$ Spinules from the stomodaeum surface, $\times 1200$. 75-Ventral half of the mantle body, inside. 76-Dorsal half of the mantle body, inside. 77-Ciliated groove.

left ventral side of the body; the branchial aperture is opened on a subterminal swelling, the atrial is situated with the posterior base at the middle of the body; both apertures are sessile. The test on the right dorsal side is hard leathery, tough, and 
very thick, attaining $0.7 \mathrm{~mm}$ near the periphery; on the attachment surface, however, it is extremely thin and translucent. The test surface is prettily coloured carmine rose as a whole and squamosed as it is divided into a number of small polygonal or round to oval areas which are $0.2-0.3 \mathrm{~mm}$ across and coloured a little more deeply near the centre. Both apertures are coloured very deeply and each marked with a white cross. There are 16 whitish finger-shaped protuberances on the surface; they are up to $0.3 \mathrm{~mm}$ in length, 7 are found near around the branchial aperture, while 9 are distributed along the dorso-posterior margin of the body. The inner surface of the test is pinkish and glistening.

The mantle is thin, yellowish orange in colour, and the whole mantle body is $3 \mathrm{~mm}$ in length. Both siphons are very prominent; the branchial siphon $0.8 \mathrm{~mm}$ long) is subterminal, and the atrial $(0.5 \mathrm{~mm}$ long) is situated near the middle. The mantle musculature consists of the muscles converging to both siphons and those surrounding the base of respective siphons and intersecting the converging muscles perpendicularly. They are practically confined to the dorsal half of the mantle body, only the ventral ends of the former reach the ventral half of the mantle body, where the mantle is very thin and the alimentary canal is seen through clearly together with the liver and gonads. There are no endocarps on the inner surface of the mantle. The epithelium of the distal part of the stomodaeum and proctodaeum is deep red and armed with many spinules, 14-17 $\mu$ in length.

Branchial tentacles are 14, all simple; larger and smaller ones alternate regularly. The ciliated groove is U-shaped. The dorsal lamina is represented by a row of languets. The inner longitudinal vessels are arranged on six branchial plications as follows on each side.

$\begin{array}{lllrllllllllllll}\text { Left } & \mathrm{D} & 1 & (11) & 1 & (4) & 1 & (10) & 2 & (9) & 2 & (8) & 2 & (6) & 1 & \mathrm{~V} \\ \text { Right } & \mathrm{D} & 1 & (9) & 1 & (4) & 1 & (10) & 1 & (12) & 1 & (10) & 1 & (4) & 1 & \text { V }\end{array}$

The second plication seems less prominent than others on both sides. The transverse and parastigmatic vessels alternate regularly. Usually two (rarely three) elongate stigmata in a mesh.

The alimentary canal describes a C-shaped loop on the ventral floor of the mantle body. The gastric portion is elongate, furnished with two hepatic lobes, the larger one of which is further subdivided into two parts. Hepatic lobes consist each of yellowish lobules which assume an elliptical outline distally. There are a number of small roundish endocarps on the intestinal wall. The distal end of the intestine forms the very small second loop. The anal margin is plain. The gonads are of the usual type of Pyrua, consisting each of 14 genital capsules.

Remarks: The present small but very beautiful pyurid reminds us of the four rather small specimens from the Nicaraguan west coast which, according to VAN NAME (1945, p. 338), may belong in Pyura lignosa Michaelsen. The simple tentacles may be a character related with the very young state of the specimen. However, 
white finger-shaped protuberances on the test surface and the less developed second branchial plication in the present specimen are quite unique. If these characters are repeatedly observed on further specimens in future, this specimen will become the first specimen of a new species. At present, however, the specimen is treated here provisionally as a form affined to the above-mentioned four specimens from the Nicaraguan west coast, which are referable to $P$. lignosa.

\section{Herdmania momus (SAVIGNY)}

(Fig. 12)

Sp. No. 948. A larger, $50 \mathrm{~mm}$ long $\times 40 \mathrm{~mm}$ high, specimen and a smaller, $30 \mathrm{~mm}$ long $\times$ $27 \mathrm{~mm}$ high, one from the Medio Island side of the Manila Channel.

Sp. No. 957a. A $35 \mathrm{~mm}$ long $\times 35 \mathrm{~mm}$ high specimen.

Sp. No. 955. Two specimens, respectively $33 \mathrm{~mm}$ long $\times 28 \mathrm{~mm}$ high and $30 \mathrm{~mm}$ long $\times 42 \mathrm{~mm}$ high.

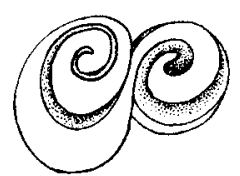

78

Fig. 12. Herdmania momus (SAvigny). Dorsal tubercle of a $50 \mathrm{~mm}$ long individual.

As the dorsal tubercle of the largest specimen (Sp. No. 948) is rosetted (Fig. 12), it is evident that these specimens belong to the typical form of the species.

\section{REFERENCES}

Drasche, R.F. (1884): Ueber einige neue und weniger bekannte aussereuropäische einfache Ascidien. Denkschriften der mathem. -naturw. Kl., vol. 48, pp. 369-386, pls. 1-8.

Gotтschaldt, R. (1898): Synascidien von Ternate. Abh. Senckenberg. Naturf. Gesell., vol. 24, no. 1 , pp. 641-660, pls. 35-36.

Hartmeyer, R. (1905): Ascidien von Mauritius. Zool. Jahrb., Suppl. 8, pp. 383-406, pl. 13, text-fig. 1.

(1919): Ascidien. In Results of Dr. E. MJoberg's Swedish Scientific Expeditions to Australia, 1910-13. K. Svenska Vetenskaps-Akad. Handl., vol. 60, no. 4, 150 pp., 25 text-figs., 2 pls.

Hastings, A.B. (1931): Tunicata. Great Barrier Reef Exped., Sci. Rep., vol. 4, no. 3, pp. 69-110, figs. 1-17, pls. 1-3.

Herdman, W.A. (1886): Report on the Tunicata collected during the voyage of H.M.S. Challenger during the years 1873-1876. Part 2. Ascidiae Compositae. Rep. Challenger Exped., Zool., vol. 14, 432 pp., 15 text-figs., 49 pls.

- (1906): Report on the Tunicata. Ceylon Pearl Oyster Fisheries, Suppl. Rep., vol. 39, pp. 295-348, pls. 1-9.

Michaelsen, W. (1905): Revision von Heller's Ascidien-Typen aus der Museum Godeffroy. Zool. Jahrb., Suppl., vol. 8, pp. 71-120, pl. 4.

(1908): Die Pyuriden (Halocynthiiden) des Naturhistorischen Museums zu Hamburg. Mitteil. Naturh. Mus. Hamburg. Wissensch. Anst., vol. 25, pp. 227-285, 2 pls.

OкA, A. (1935): Report of the Biological Survey of Mutsu Bay 28. Ascidiae Simplices. Sci. Rep. Tôhoku Imp. Univ., vol. 10, no. 3, pp. 427-466, 35 text-figs. 
Slutter, C. PH. (1885): Ueber einige einfache Ascidien von der Insel Billiton. Natuurk. Tijdschr. Neder. Ind., vol. 45, pp. 160-232, pls. 1-9.

- (1891): Die Evertebraten aus der Sammlung des Kgl. naturw. Vereins in Nederl. Ind. in Batavia. Zugleich eine Skitzze der Fauna des Java-Meeres mit Beschreibung der neuen Arten. Ascidiae Simplices. Natuurk. Tijdschr. Neder. Ind., vol. 50, pp. 329-348, pls. 1-2.

- (1895): Tunicaten. Semon Zool. Forschungsreise, V. Jenaische Denkschriften, vol. 8, pp. 161-186, pls. 6-10.

- (1904): Die Tunicaten der Siboga-Expedition. I Abt. Die socialen und holosomen Ascidien. Siboga-Exped., 56a, 126 pp., 15 pls.

- (1909): Die Tunicaten der Siboga-Expedition. II Abt. Die merosomen Ascidien. SibogaExped., 56b, 112 pp., 2 text-figs., 8 pls.

- (1919): Ueber einige alte und neue Ascidien aus dem Zoologischen Museum von Amsterdam. Bijdr. Dierkunde, af1. 21, pp. 1-21, pl. 1.

Tokioka, T. (1950): Ascidians from the Palao Islands. I. Publ. Seto Mar. Biol. Lab., vol. 1, no. 3, pp. 115-150, 23 text-figs., pls. 9-10.

(1952): Ascidians collected by Messrs. Renzi WAdA and Seizi WadA from the pearl oyster bed in the Arafura Sea in 1940. Publ. Seto Mar. Biol. Lab., vol. 2, no. 2, pp. 91-142.

(1953): Ascidians of Sagami Bay. Tokyo, 315 pp., 25 text-figs., 80 pls.

(1954): Contributions to Japanese ascidian fauna. VII. Invertebrate fauna of the intertidal zone of the Tokara Islands. VII. Ascidians. Publ. Seto Mar. Biol. Lab., vol. 3, no. 3, pp. 239-264, 2 text-figs., pls. 18-37.

(1967): Pacific Tunicata of the United States National Museum. U.S. Nat. Mus. Bull. 251, 247 pp., 105 figs.

Van Name, W.G. (1902): The ascidians of the Bermuda Islands. Trans. Connecticut Acad. Sci., vol. 11 , pp. 325-412, pls. 46-64.

- (1918): Ascidians from the Philippines and adjacent waters. U.S. Nat. Mus. Bull. 100, vol. 1, part 2, pp. 49-174, pls. 23-33, 115 text-figs.

(1921): Ascidians of the West Indian region and southeastern United States. Bull. American Mus. Nat. Hist., vol. 44, pp. 283-494, figs. 1-159.

(1930): The ascidians of Porto Rico and the Virgin Islands. Sci. Surv. Porto Rico and Virgin Ids., New York Acad. Sci., vol. 10, pp. 401-512, figs. 1-73, pls. 5-8.

(1945): The North and South American ascidians. Bull. American Mus. Nat. Hist., vol. 84, 476 pp. 31 pls., 327 text-figs. 